\title{
The Fate of Nitrogen from Soil to Plants: Influence of Agricultural Practices in Modern Agriculture
}

\author{
Maria Giordano $^{1, *(\mathbb{C})}$, Spyridon A. Petropoulos ${ }^{2} \mathbb{D}$ and Youssef Rouphael ${ }^{1} \mathbb{C}$ \\ 1 Department of Agricultural Sciences, University of Naples Federico II, Via Universita 100, 80055 Portici, Italy; \\ youssef.rouphael@unina.it \\ 2 Department of Agriculture Crop Production and Rural Environment, University of Thessaly, Fytokou Street, \\ 38446 Nea Ionia, Magnissia, Greece; spetropoulos@uth.gr \\ * Correspondence: maria.giordano@unina.it
}

Citation: Giordano, M.; Petropoulos, S.A.; Rouphael, Y. The Fate of Nitrogen from Soil to Plants: Influence of Agricultural Practices in Modern Agriculture. Agriculture 2021, 11,944. https://doi.org/10.3390/ agriculture11100944

Academic Editor: Jochen Mayer

Received: 4 August 2021

Accepted: 27 September 2021

Published: 29 September 2021

Publisher's Note: MDPI stays neutral with regard to jurisdictional claims in published maps and institutional affiliations.

Copyright: (c) 2021 by the authors. Licensee MDPI, Basel, Switzerland. This article is an open access article distributed under the terms and conditions of the Creative Commons Attribution (CC BY) license (https:// creativecommons.org/licenses/by/ $4.0 /)$.

\begin{abstract}
Nitrogen is an element present on Earth in different forms, such as gaseous in the air, dissolved in water, immobilized in the soil, as well as biologically bound in all living organisms. The transition from one form to another constitutes the nitrogen cycle. Current agricultural systems rely on nitrogen fertilizers, which represent the reactive or biologically available nitrogen in soil. The excessive presence of reactive nitrogen in the environment has become a threat to soil, water, and air. The increasing demands for food in the world are associated with significant increase in nitrogen fertilizers inputs which threatens the environment and living organisms. The quantities of nitrogen used per capita in developed countries exceed those in developing countries. However, developed countries are regulated by restrictions of fertilizers inputs in agriculture, whereas such regulations do not exist in most of the developing countries. The need to resort to alternative and eco-sustainable strategies to mitigate the pollution related to human activities, is increasingly evident. This review aims to highlight the fate of nitrogen through the main agricultural practices in modern agriculture. Special attention was given to rocket (Eruca sativa) which is considered a nitrate hyper-accumulator and was used as a case study in the present review. Finally, some eco-sustainable solutions, useful for mitigating or preventing the excessive release of harmful forms of nitrogen into the environment, were also discussed.
\end{abstract}

Keywords: nitrogen fertilizers; $\mathrm{N}_{2} \mathrm{O}$ emissions; $\mathrm{NH}_{3}$ volatilization; nitrate leaching; nitrogen turnover; climate change; environmental pollution; eco-sustainable agriculture

\section{Introduction}

Modern agriculture is called upon to respond to the increasing demands for food in an ever-growing world population, which according to experts is expected to reach 9 billion people in 2050 [1,2]. To produce food in larger quantities, agriculture must continuously resort to fertilizers [3]. The use of nitrogen-based fertilizers is estimated in millions of tons (155 Mt) [4] and has allowed the increase in production of crops and food all over the world. In countries such as India, whose diet is supported almost exclusively by agricultural products [5], urea accounts for $80 \%$ of the fertilizers used in the farming sector. However, the continuous replenishment of organic and inorganic forms of nitrogen in soils has altered the natural cycle of this element over the past 50 years [2,5]. An excessive quantity of nitrogen fertilizers is supplied in the soil, because only about half of the applied quantity is available and is finally absorbed by crops [6]. The other half is dispersed in the environment in different forms [5,7]. Staple foods such as Brassica napus L., used for oil production in China are cultivated by using about $300 \mathrm{~kg} \mathrm{~N} \mathrm{ha}^{-1}$, but actually plants take up only $30-50 \%$ of the total nitrogen supplied [8].

Nitrogen compounds, derived from fertilizers and which are harmful to environmental and human health, are nitrates, nitrogen oxides $\left(\mathrm{N}_{2} \mathrm{O}\right)$ and ammonia [5,9-11]. Strong releases of $\mathrm{N}_{2} \mathrm{O}$ from agricultural soils to the atmosphere were recorded in the first hours 
after fertilizers application [12]. However, there is no linear relationship between the amount of fertilizers and $\mathrm{N}_{2} \mathrm{O}$, as soil and environmental characteristics can affect these emissions [5,11,13-16]. Moreover, rice crops and ruminant livestock farms release methane, while nitrous oxide $\left(\mathrm{N}_{2} \mathrm{O}\right)$, carbon dioxide $\left(\mathrm{CO}_{2}\right)$, and methane $\left(\mathrm{CH}_{4}\right)$ are gases related to greenhouse cultivation of crops. The increase of these gases in the atmosphere is translated into a change in natural phenomena, such as the alteration in the flow of monsoons, the higher frequency and intensity of hurricanes, the melting of glaciers, and rising sea levels [17]. Therefore, human activities through the agricultural practices, is highly participating in environmental pollution and the ongoing climate change.

The evaluation of nitrogen losses from the agricultural context to environment has been defined as nitrogen footprint [17-20]. It can refer to the use of fertilizers, the consumption of agricultural products, and the production of energy [17-20]. Countries that import or export agricultural products significantly affect nitrogen footprint. The correct assessment of nitrogen inputs and outputs in ecosystems could be useful to establish whether this ecosystem is directed towards nitrogen use efficiency (NUE) or negative use of nitrogen. Nitrogen footprint can also refer to food consumption around the world [21,22]. The consumption of nitrogen through food varies from 15 to $47 \mathrm{~kg}$ of nitrogen per capita per year. The reason for this difference lies above all in differences in consumption of proteins and the different nitrogen turnover throughout the world [19]. In this context, North America (39 kg per year)and some European countries (24-29 kg N per capita per year) show a higher nitrogen footprint, compared to Asia (2-11 kg N per capita per year) [2]. Moreover, the nitrogen footprint linked to the consumption of fossil energy is greater in America than in China, but China has higher values than Europe [2]. The nitrogen footprint can also vary according to the eating habits imposed by cultural and religious differences [23]. In India, where several different religions coexist, $N$ footprint values of 10.7, 11.45, 11.47, $7.39 \mathrm{~kg}$ $\mathrm{N}$ per capita per year have been estimated, referring to the eating habits of Hinduists, Muslims, Christians, and Buddhists, respectively [23].

The purpose of this review was the assessment of nitrogen turnover within the environmental and agricultural context. Attention was given to rocket, which is a widespread vegetable worldwide, is consumed mainly as a salad, and which has been defined as a nitrate hyper-accumulator. Eco-sustainable mitigation strategies against the dispersion of harmful forms of nitrogen into the environment, were also discussed.

\section{Nitrogen in the Soil: Origin and Destiny}

\subsection{Nitrogen Absorption through the Roots}

Nitrogen makes up $78.09 \%$ of our atmosphere, where it is found in a non-reactive form $\left(\mathrm{N}_{2}\right)$. In soils however, it is present in small quantities, but in very reactive forms (Nr) [2]. These forms can be inorganic and reduced, such as ammonia, and ammonium, and/or oxidized ones, such as nitric acid $\left(\mathrm{HNO}_{3}\right)$, nitrous acid $\left(\mathrm{HNO}_{2}\right)$, nitrate ion $\left(\mathrm{NO}_{3}{ }^{-}\right)$, nitrogen oxides (NOx), nitrous oxide $\left(\mathrm{N}_{2} \mathrm{O}\right)$, nitrogen pentoxide $\left(\mathrm{N}_{2} \mathrm{O}_{5}\right)$, and peroxyacetyl nitrate (PAN) [5]. The organic forms of nitrogen in soil include amino acids, proteins, amines, urea, and other nitrogen containing organic molecules. Among these forms, ammonium and nitrate are the ones that are absorbed the fastest by plants [24]. An indispensable element required for the absorption of ammonium and nitrate is water. In nitrogen cycle (e.g., soil-plant-atmosphere), water allows the absorption of nitrogen and other nutrients through the roots, thus influencing plant growth [25]. The accumulation of nitrogen reserves within plants, or the remobilization of nitrogen from one plant part to another, occurs thanks to the water movement. This allows the plant to have nitrogen deposits without promptly resorting to absorption from the environment and results in energy savings and reduced nitrogen losses [24]. On the other hand, root hydraulic conductance and water uptake were found to be increased, following the replenishment of nitrate in the soil in Helianthus annuus cv. Holiday, Solanum lycopersicum, and Cucumis sativus [24]. Therefore, water use efficiency (WUE) and nitrogen use efficiency (NUE) are interrelated and may determine crop yield $[24,26]$. 
Deep roots may ensure the reduction in nitrogen leaching in the soil [24]. Nitrogen in turn affects root growth, as high concentrations of nitrates can suppress the growth of lateral roots [24]. On the other hand, under reduced nitrogen conditions, there is an increase in root hairs and root density in terms of length and thickness [27]. At present, the relationship between water and absorbed nitrogen is altered by the climate change which causes sudden and extreme rainfalls, so the development of cultivars with high WUE and NUE is increasingly difficult [24].

\subsection{Activity of Microorganisms}

Soils are rich in nitrogen thanks to the activity of nitrogen-fixing microorganisms, which create symbiotic relationships with some plant species. Biologically fixed nitrogen (BNF) is an important nitrogen source that guarantees more nitrogen than manures and chemical fertilizers $[28,29]$. The symbiosis between the genus Rhizobium and leguminous plants fixes a quantity of nitrogen within the range of $15-200 \mathrm{~kg} \mathrm{ha}^{-1}$ [24]. Such associations are also effective in conditions of water stress or high temperatures [24]. Arbuscular mycorrhizal fungi are another group of microorganisms that are important for nutrients absorption and for improving plant tolerance to water stress [30,31]. The inoculation with these two types of microorganisms provides crops with a good supply of water and nitrogen [24]. Moreover, the correct combination of beneficial microorganisms can guarantee the success of crops, such as legumes, even under nutrient- and/or water-deficient environments [24]. From this point of view, nitrogen-fixing activity of these microorganisms could be an alternative to reduce the inputs of chemical fertilizers in agriculture.

\subsection{Loss of Nitrogen from the Soil}

The gaseous forms of nitrogen released due to human activities, are nitrous oxide $\left(\mathrm{N}_{2} \mathrm{O}\right), \mathrm{NOx}\left(\mathrm{NO}+\mathrm{NO}_{2}\right)$, and ammonia [5]. These gases are emitted either during the cultivation and harvesting of crops, or when fertilizers and pesticides are produced [5]. Nitrogen can leave agricultural systems through nitrate leaching or crop harvest [5].

\subsubsection{Volatilization of Ammonia}

The release of ammonia from soils has an impact on air, water, animal, and human health, particularly in areas where animal nutrition is intensified, and in countries where there is no regulation of fertilizers use, such as developing countries [2,32]. Ammonia can bind to acidic compounds $\left(\mathrm{SO}_{4}{ }^{2-}\right.$ and $\left.\mathrm{NO}_{3}{ }^{-}\right)$and form an inorganic aerosol and acid rain [2]. The volatilization of ammonia is very rapid when fertilizers containing ammonium are applied, for example, ammonium nitrate, ammonium sulfate, and urea $\left(\mathrm{NH}_{4} \mathrm{NO}_{3}, \mathrm{NH}_{4} \mathrm{SO}_{4}\right.$ and $\mathrm{CH}_{4} \mathrm{~N}_{2} \mathrm{O}$, respectively) [2]. This process is influenced by edaphic and climatic factors and in fact it is favored in soils with high $\mathrm{pH}$, but also with acidic or neutral $\mathrm{pH}$ in the case of urea [2]. The hydrolyzed urea in soil solution increases the $\mathrm{pH}$ and determines the reduction of the ammonium ion into ammonia [33-35]. Ninety percent (\%) of ammonia emissions ( 7.6 million $\mathrm{kg} \mathrm{ha}^{-1}$ ) come from animal husbandry which derives from the hydrolysis of urea contained in urine and feces [36].

The increase of ammonia in the atmosphere from dairy manure and the total $\mathrm{N}$ fraction deposited in manure were elaborated with the use of $\delta^{15} \mathrm{~N}$ isotopes in various laboratory studies [32]. These studies showed that ammonia was emitted into the air in large quantities in the early days of manure storage and subsequently a decline in volatilization was recorded. Chalk et al. [32] reported the measurements made over more than 30 years, which evaluated the accumulation of $\delta^{15} \mathrm{~N}$ isotopes in six different areas in Yellowstone National Park where grazing from ungulate took place. The data showed that $\delta^{15} \mathrm{~N}$ was present in urine in greater quantities than in soil $(0-20 \mathrm{~cm})$ and plants, and most nitrogen was found as $\mathrm{NH}_{3}$ emitted from soil. These results were confirmed by laboratory studies with plants and soil treated with ungulate urine containing $\delta^{15} \mathrm{~N}$, where $\delta^{15} \mathrm{~N}$ accumulated in soils and plants treated with urine, compared to controls without 
urine. Furthermore, the various studies showed that $\mathrm{NH}_{3}$ volatilized from soil could be absorbed by plant shoots [32].

Enrichment with $\delta^{15} \mathrm{~N}$ and subsequent release in the form of ammonia has been shown in composts of agricultural residues, such as corn silage and cattle manure compost $[32,37]$. The use of $\delta^{15} \mathrm{~N}$ has also made it possible to record an increase in $\mathrm{NH}_{4}{ }^{+}$and $\mathrm{NO}_{3}{ }^{-}$in manure composted with rice or sawdust. In these studies, it was shown that $\mathrm{NH}_{4}{ }^{+}$is lost at the beginning of the composting process by volatilization of $\mathrm{NH}_{3}$ or with nitrification, and $\mathrm{NO}_{3}{ }^{-}$is subsequently lost through denitrification [32].

\subsubsection{Emissions of $\mathrm{N}_{2} \mathrm{O}$ and Odd Oxides of Nitrogen}

$\mathrm{N}_{2} \mathrm{O}$ emission into the air is considered as nitrogen loss from soil, which strongly contrasts the NUE. $\mathrm{N}_{2} \mathrm{O}$ activity as a greenhouse gas has been estimated to be 300 times greater than $\mathrm{CO}_{2}[5,17]$. Furthermore, $\mathrm{N}_{2} \mathrm{O}$ reacts with oxygen forming nitric acid and reducing the amount of ozone in the stratosphere, contributing to the greenhouse effect [2]. The combustion of fuels from cars and industries also releases large quantities of $\mathrm{N}_{2} \mathrm{O}$, so that the World Health Organization (WHO) has identified pulmonary and cardiovascular diseases in children and adults resulting from excessive or continuous exposure to this gas [38]. Large quantities of $\mathrm{N}_{2} \mathrm{O}$ have been recorded in ruminant farms, too [39-41]. $\mathrm{N}_{2} \mathrm{O}$ can be emitted from the soil both under aerobic conditions of nitrification and anaerobic conditions of denitrification [42,43]. The microbial producers of $\mathrm{N}_{2} \mathrm{O}$ are ammonia oxidizing archaea, ammonia oxidizing bacteria, ammonia oxidizing methanotrophs, fungal and denitrifying bacteria [32].

The use of $\delta^{15} \mathrm{~N}-\mathrm{N}_{2} \mathrm{O}$ isotopes was used to follow the path of $\mathrm{N}_{2} \mathrm{O}$ from the soil [32]. Some studies have shown that heavy rains increase the gas emissions from soil. It has been observed that both ammonia monooxygenase and bacterial nitrate reductase transcripts increase because of the production of $\mathrm{N}_{2} \mathrm{O}$ after heavy rains, demonstrating that both denitrifying and nitrifying microorganisms increase their activity for $\mathrm{N}_{2} \mathrm{O}$ production, with rain [32]. Nitrification is the oxidation process that converts ammonium into hydroxylamine $\left(\mathrm{NH}_{2} \mathrm{OH}\right), \mathrm{NOH}$, and $\mathrm{NO}_{2}{ }^{-}$, while both $\mathrm{NH}_{2} \mathrm{OH}$ and $\mathrm{NOH}$ can produce $\mathrm{N}_{2} \mathrm{O}$ [44]. $\mathrm{N}_{2} \mathrm{O}$ can be formed through incomplete nitrification, called nitrifier denitrification [39], which is the reduction of $\mathrm{NO}_{2}{ }^{-}$to $\mathrm{N}_{2} \mathrm{O}$, caused by denitrifying microorganisms in intermediate oxic-anoxic conditions. Denitrification is the anaerobic reduction of $\mathrm{NO}_{3}{ }^{-}$ by denitrifying bacteria, with the formation of $\mathrm{NO}_{2}{ }^{-}, \mathrm{NO}, \mathrm{N}_{2} \mathrm{O}$, and $\mathrm{N}_{2}$ gases. In the denitrification process, $\mathrm{N}_{2} \mathrm{O}$ originates from $\mathrm{NO}_{3}{ }^{-}$or $\mathrm{NO}$ [19]. $\mathrm{N}_{2} \mathrm{O}$, produced through the denitrification of organic amendments, is much greater than that derived from nitrification or that released from fertilizing soils with mineral nitrogen or without nitrogen amendments $[39,45,46]$. The gases released from the soil after denitrification may differ depending on the amount of $\mathrm{NO}_{3}{ }^{-}, \mathrm{O}_{2}$, carbon as the energy source, $\mathrm{pH}$, and microbial community in the soil [47]. The gas spread in the soil is very important, and it is related to the structure and the anaerobic conditions of the soil $[48,49]$. Soil $\mathrm{pH}$ also affects $\mathrm{N}_{2} \mathrm{O}$ production as low $\mathrm{pH}$ inhibits the $\mathrm{N}_{2} \mathrm{O}$ reductase enzyme, and under these conditions the $\mathrm{N}_{2} \mathrm{O} / \mathrm{N}_{2}$ ratio increases. On the other hand, high $\mathrm{pH}$ values favor the complete denitrification to form $\mathrm{N}_{2}$, so the $\mathrm{N}_{2} \mathrm{O} / \mathrm{N}_{2}$ ratio is reduced [50]. Low temperatures may block the activity of nitrous oxide reductase and denitrification [39].

$\mathrm{N}_{2} \mathrm{O}$ is also produced during the composting of plant tissues [32]. When degradable organic matter is present in the soil, large quantities of both $\mathrm{C}$ and $\mathrm{N}$ are available and large quantities of $\mathrm{N}_{2} \mathrm{O}$ are released. $\mathrm{N}_{2} \mathrm{O}$ is abundant if grain legumes residues [50], grassclover [50,51], intercropped clover [50] or cover crops [52,53] are incorporated into soil. During the growth of unfertilized legumes, lower amounts of $\mathrm{N}_{2} \mathrm{O}$ are released from the soil. However, during plant senescence high amounts of $\mathrm{N}_{2} \mathrm{O}$ are released from roots and root nodules. The incorporation of plant tissues with low $\mathrm{C} / \mathrm{N}$ ratio causes the strong release of $\mathrm{N}_{2} \mathrm{O}$ [54]. In this context, legume residues should release more $\mathrm{N}_{2} \mathrm{O}$ than cereals or grasses. However, it has been found that if the carbon source is degradable and readily available the release of $\mathrm{N}_{2} \mathrm{O}$ is not affected by the $\mathrm{C} / \mathrm{N}$ ratio [55]. 
Odd oxides of nitrogen $\left(\mathrm{NOx}=\mathrm{NO}+\mathrm{N}_{2} \mathrm{O}\right)$ also play an important role in the production of smog and can derive from soil, the combustion of fossil residues, lightning and fires [32]. NO concentration in the atmosphere, measured through $\delta^{15} \mathrm{~N}$, was found to increase after fertilization with urea and ammonium bicarbonate while nitrification and denitrification are also involved in NO production [32].

\subsubsection{Nitrate Leaching}

Nitrate in the soil originates from the oxidation of ammonium (nitrification). Excessive fertilization leads to losses of $\mathrm{N}$ in the form of $\mathrm{NO}_{3}{ }^{-}$through leaching and its dispersion into the environment, having an impact on soil productivity, food safety, water, and air quality [56]. Nitrate nitrogen is in anionic form and therefore can be soluble in the water. In very drained soils, it percolates into soil, moving away from the rhizosphere. Rain and irrigation favor its removal into soil layers [2]. Therefore, its presence in the soil depends on the type of soil (structure and texture), and the meteorological conditions [2]. It can be higher in sandy soils than clay ones [2,50]. At the end of the production cycle, or after crop losses, the nitrate content in the soil increases, and with it the possibility of nitrogen leaching if heavy rains occur [57]. Drought periods also influence nitrate leaching in both conventional and organic systems. In the two systems in fact slow mineralization leads to the accumulation of nitrates, which will be quickly leached in case of rain incidence.

Nitrate leaching can cause eutrophication and proliferation of algae in reservoirs, and can reach humans via drinking water, causing a disease known as Blue-Baby Syndrome in which nitrate binds hemoglobin, hindering the transport of oxygen [2,58]. A total of $10 \mathrm{mg} \mathrm{L}^{-1}$ is the maximum permitted level for nitrate concentration in water $[59,60]$. It has been estimated that agricultural activities and industries release $161 \mathrm{Tg}$ of nitrate [2].

Losses of nitrate are evident in various crops, especially vegetable plants that usually do not have deep roots and therefore lose most of the nitrogen supplied with fertilizers. According to de Barros Sylvestre et al. [61], 165 and $149 \mathrm{~kg} \mathrm{~N}^{-1}$ were considered the nitrogen doses that corresponded to the maximum yield for looseleaf lettuce and crisphead lettuce, respectively. However, after the application of $150 \mathrm{~kg} \mathrm{~N} \mathrm{ha}^{-1}$, the nitrogen taken up by lettuce plants was $57.9 \mathrm{~kg} \mathrm{ha}^{-1}$, while $92.1 \mathrm{~kg} \mathrm{ha}^{-1}$ remained in the soil [61]. The more damaging condition is that in which the vegetable cultivation fields are located near waterways. According to some authors, the low application rates of nitrogen fertilizers to vegetable crops reduces the yield but also the nitrate leaching [61]. The same authors [61] examined the effect of seven doses of nitrogen $\left(0,30,60,90,120,150\right.$, and $\left.180 \mathrm{~kg} \mathrm{~N} \mathrm{ha}^{-1}\right)$ in the form of urea $(47 \% \mathrm{~N})$, applied at different times after planting, on the yield and nitrate concentration of crisphead lettuce plants (Lactuca sativa L.) grown in two seasons (summer and winter). The nitrate and ammonium content found at a depth of 20-60 cm was considered as nitrogen leached into soil. Doses higher than $60 \mathrm{~kg} \mathrm{~N} \mathrm{ha}^{-1}$ increased nitrogen leaching, while the highest ammonium content was found in $20-40 \mathrm{~cm}$ (summer) and 0-20 cm (winter) layers and the highest nitrate content was recorded in 40-60 cm (summer).

\section{Effect of Agricultural Practices on the Fate of Nitrogen in Soil and Plants}

The presence of nitrogen in the soil is mainly linked to soil organic matter (SOM) rather than minerals, and agricultural practices are responsible for the nitrogen balance in soil [56]. Soil organic carbon (SOC) represents the major component of soil organic matter and influences crop productivity. It includes labile or active carbon, which refers to the $\mathrm{C}$ of microbial biomass, and carbohydrates in soil [62]. When microbes mineralize soil organic matter, they release $\mathrm{N}_{2} \mathrm{O}$, so if the soil is rich in either organic matter or organic carbon, high amounts of $\mathrm{N}_{2} \mathrm{O}$ can be recorded [50]. When SOC increases, other factors contribute to raising $\mathrm{N}_{2} \mathrm{O}$ emissions, such as the type of crop, or the type of rotations [56] (Figure 1). 


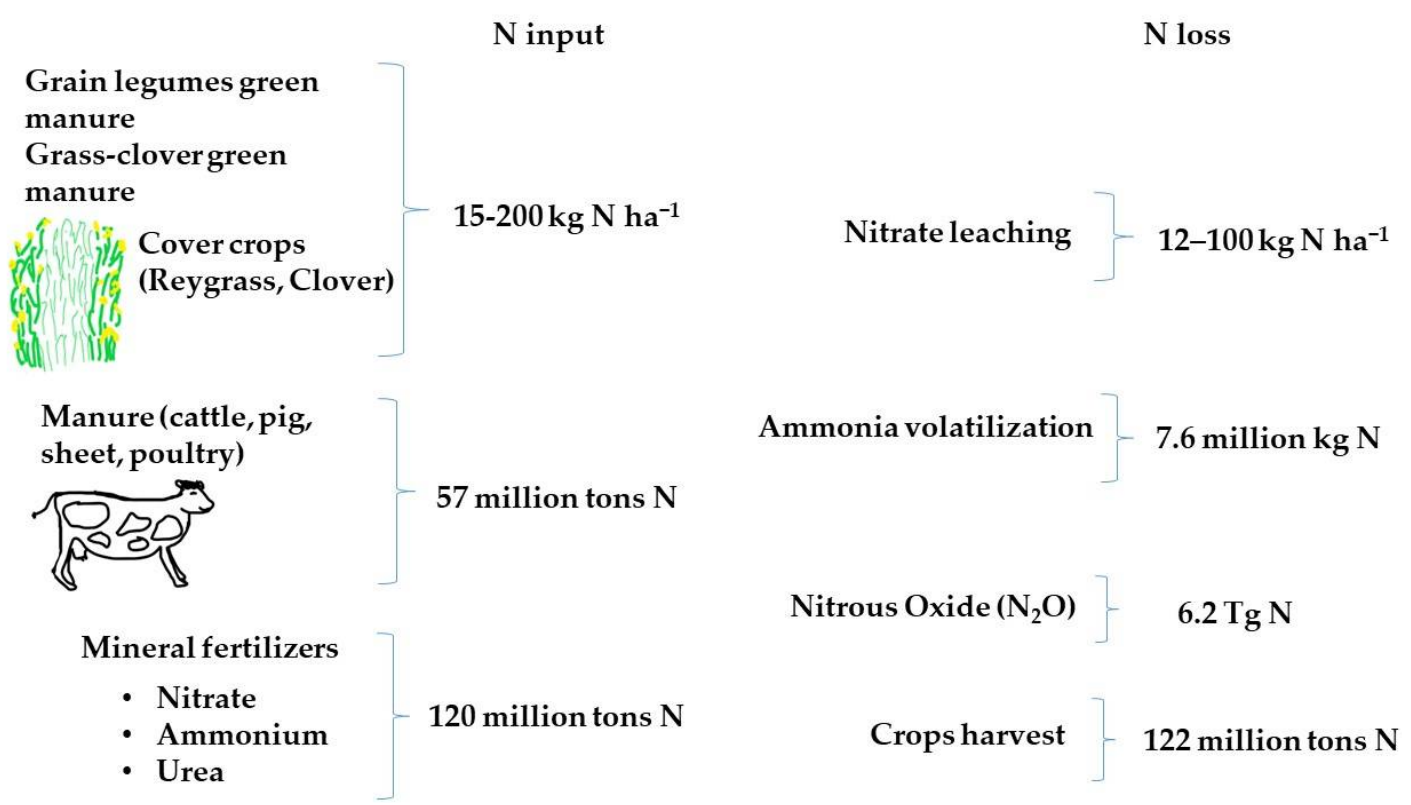

Figure 1. Values of nitrogen $(\mathrm{N})$ inputs and losses through worldwide agricultural activities.N input references: $[5,24,29] ; \mathrm{N}$ loss references: $[2,5,36,61]$.

Inorganic soil nitrogen represents less than $10 \%$ of the total soil nitrogen, while $90 \%$ is organic nitrogen, and its turnover is important for the nitrogen supply to plants. Organic nitrogen consists of high molecular weight polyphenols and amino acids. Amino acids are quickly mineralized and immobilized by microorganisms. The turnover of amino acids by microorganisms is slowed if glucose is added [63]. The addition of inorganic $\mathrm{N}$ favors the decomposition of added amino acids compared to pre-existing amino acids in the soil. Some studies have shown that organic amendments, combined with inorganic fertilizers, increased nitrogen retention in the soil [64].

The effect of agricultural practices on soil nitrogen dynamics was evaluated by three consecutive cultivations of maize plants in pots on soil, containing two levels of nitrogen fertilizer (100 and $200 \mathrm{~kg} \mathrm{~N} \mathrm{ha}^{-1}$ ) and maize straw [64]. The purpose of the experiment was to evaluate the conversion of the fertilizer used $\left.\left({ }^{15} \mathrm{NH}_{4}\right) 2 \mathrm{SO}_{4}\right)$ into soil organic $\mathrm{N}$ and amino acid $\mathrm{N}$. The application of a high dose of fertilizer combined with amendment increased the organic $\mathrm{N}$ content in the soil by $20.1 \%$. Both the combination of high nitrogen dose and low nitrogen dose with amendment increased the $\mathrm{N}$ amino acid content in the soil by approximately $12.5 \%$. The increase in organic and amino acid $\mathrm{N}$ was recorded at the end of the first cultivation. In subsequent crops, organic and amino acid nitrogen was reducedin the soil. According to the authors, $34 \%$ and $21 \%$ of the ${ }^{15} \mathrm{~N}$ fertilizer were converted into organic $\mathrm{N}$ and amino acid, respectively, in the first 10 days of fertilization, while in the following days this percentage was reduced. They showed that amino acids represented the most labile fraction of soil organic nitrogen, compared to other organic fractions. Amino acids can be directly absorbed by soil microbes through transporters on their membranes. Proteins must first be broken down into peptides and amino acids to be absorbed. According to the authors, the combination of amendments and fertilizers allowed a greater retention of $\mathrm{N}$ in the soil, especially in the form of amino acids. These amino acids were available to the plants which absorbed them thus increasing NUE. In the treatment where only fertilizer was applied, the excessive fertilizer was dispersed more quickly in the soil layers rather than being retained in the soil with the organic material [64].

The dynamics of nitrogen from soil to plants were shown by Smith and Chalk [65] in a work that analyzed the results of 100 works published within the last 60 years, which refer to the use of inorganic and organic fertilizers enriched with ${ }^{15} \mathrm{~N}$. According to the authors, the distribution of ${ }^{15} \mathrm{~N}$ in the soil and over time depends not only on the form of fertilizer but also on edaphic, environmental and microbiological factors, as well as on preceding 
crops. $\mathrm{NO}_{3}{ }^{-}$and $\mathrm{NH}_{4}{ }^{+}$can remain in the soil in labile form as well as they can be bound to clay in the form of $\mathrm{NH}_{4}{ }^{+}$. A portion of ${ }^{15} \mathrm{~N}$ was found, as organic $\mathrm{N}$ immobilized in soil microbes, and was made available for subsequent crops after remineralization. The authors highlighted that, at the end of the first year of application, if ${ }^{15} \mathrm{~N}$ was introduced into the soil as synthetic fertilizer, its recovery from crops, as \% of $\mathrm{N}$, was higher than ${ }^{15} \mathrm{~N}$ introduced as manure or organic residues. On the other hand, when ${ }^{15} \mathrm{~N}$ was introduced into the soil with manure and organic residues, it increased into the crops in the following years [65].

\subsection{Tillage Practices}

Tillage practices are considered important to improve the organic matter content of the first layers of the soil. With tillage, the SOM is broken and mixed with the soil, accelerating its decomposition [56]. Tillage practices have a double effect: in the short term, they immobilize nitrogen and make it less available to plants, while in the long term, they enrich the upper layers of the soil with labile and available $N$ [56]. Couto-Vázquez and González-Prieto [56] evaluated the movement of $\mathrm{N}$ in different soil layers and in plants by applying a crop rotation of silage maize (Zea mays L.) and Italian ryegrass (Lolium multiflorum L.), grown with two tillage practices, namely conventional plow tillage, and minimum tillage during 14 years. The minimum tillage system was applied for eight years without tillage, and in the six subsequent years it was implemented with a bentleg subsoiler to avoid soil compaction. In the plow tillage system, the soil was plowed twice a year. To follow the path of nitrogen from soil to plants, the authors used the isotope ${ }^{15} \mathrm{~N}$ fertilizer in both systems, and in three periods, October, March, and May of the following year. The authors analyzed the nitrogen accumulated in soil $(0-60 \mathrm{~cm})$ and plants. In the samples taken in October, the authors found in the soil of both systems a higher pool of ${ }^{15} \mathrm{~N}$ fertilizer in the nitrate form than the ammonium one, while its quantity decreased with increasing soil depth. Moreover, on this date, the effect of the two systems was not significant. In the samples taken later (March and May), the ${ }^{15} \mathrm{~N}$ fertilizer was influenced by the tillage system, the depth of the soil, and their interaction, with more nitrogen being recorded in the minimum tillage system. The recovery efficiency of nitrogen (REN) in plants had the highest values in May and in the plow tillage system, as compared to the minimum tillage system. As for the ${ }^{15} \mathrm{~N}$ fertilizer found in the soil after harvest, its quantity was higher in October than in March and May. The amount of $\mathrm{N}$ found in the harvested plants was greater in minimum tillage than in the plow tillage. Furthermore, the percentage of $\mathrm{N}$ was higher in ryegrass than in maize. Finally, at the end of the experiment, the authors found that ${ }^{15} \mathrm{~N}$ fertilizer, immobilized in the soil at root level, was greater in the minimum tillage system than the plow tillage. The authors thus highlighted that the minimum tillage system offered less labile nitrogen to plants in the short term, while in the long term it offered more nitrogen available in the upper soil layers.

\subsection{Organic Farming}

In recent years, there has been a lot of interest in organic farming around the world, and in Europe about $6 \times 10^{6}$ hectares of agricultural land are devoted to organic farming $[66,67]$. Organic farming is an agricultural practice in which the health of the environment and people is guaranteed through the preservation of the nutrientscycle, while synthetic and external energy sources are not used [68]. Scholars are trying to understand if organic farming contributes both to the release of greenhouse gases and increases in nitrate leaching $[69,70]$. In both organic and non-inorganic crops, crop residues are left on the soil. However, in organic farming, there are longer rotations, such as green manures, leys, cover crops, and intercrops [71]. In Europe, these rotations are subject to specific regulations [72], according to which the use of synthetic nitrogen fertilizers and pesticides is not allowed. According to this regulation, agricultural systems that use inorganic fertilizers, pesticides, and short rotations are defined as conventional farming or non-organic farming. 
In organic farming, there are other organic sources, such as animal manures and composts [73]. The release of $\mathrm{N}$ from the different organic sources depends on the quantity of $\mathrm{N}$ contained in these sources, on the degradation of these sources, and the $\mathrm{C} / \mathrm{N}$ ratio. When the $\mathrm{C} / \mathrm{N}$ ratio of the organic sources added to the soil is high, for example 12:1 (pig slurry or poultry manure) or 21:1 (cattle slurry), the contained nitrogen is released very slowly. The organic matter introduced into organic crops favors the growth, development, and diversity of decomposing organisms, and the higher activity of these microorganisms compared to non-fertilized soils or soils fertilized with mineral fertilizers [74,75]. Carbon and nitrogen from microbial biomass, enzymatic activities, such as dehydrogenase, urease, and protease, were found significantly higher in organic crops than in non-organic ones [75]. Generally, nitrogen is immediately immobilized by microorganisms, while its mineralization can even begin several months later $[50,76]$. The slow mineralization of nitrogen in organic fertilizers and plant residues makes it necessary to synchronize the release of $\mathrm{N}$ from these sources, and the uptake of $\mathrm{N}$ by plants, otherwise there is an accumulation of mineral and available nitrogen in the soil, which will subsequently be lost by volatilization and leaching. According to Intergovernmental Panel on Climate Change(IPCC) [77], 1\% of nitrogen supplied with fertilizers and organic sources is re-emitted into the environment in the form of $\mathrm{N}_{2} \mathrm{O}$. In non-organic systems, $\mathrm{N}_{2} \mathrm{O}$ emissions were observed immediately after fertilization in moist soil [50], while in organic systems such emissions were observed after the introduction of plant residues into the soil [51,78]. As organic systems have more organic matter, they were responsible for higher $\mathrm{N}_{2} \mathrm{O}$ emissions [50].

Liquid organic amendments had a high content of $\mathrm{NH}_{4}-\mathrm{N}$ and easily degradable carbon and nitrogen, compared to solid organic amendments, so that the release of $\mathrm{N}_{2} \mathrm{O}$ was also higher [78-80]. The rotation systems and their management might also influence nitrogen mineralization (potentially mineralizable $\mathrm{N}$ (PMN) pool). Unlike non-organic rotations, biological rotations include pulses and temporary fodder crops (such as alfalfa, clover, and ryegrass). Some authors reported that organic systems release up to $300 \mathrm{~kg} \mathrm{~N} \mathrm{ha}^{-1}$ and that the more the rotations were different from each other, the more $\mathrm{N}$ was mineralizable. In this context, mineralizable $\mathrm{N}$ was $112 \%$ higher than the mineralizable nitrogen of conventional systems [50].

After one year and three years of grass and clover ley presence, 61 and $95 \mathrm{~kg} \mathrm{~N} \mathrm{ha}^{-1}$ were found in the $0-90 \mathrm{~cm}$ soil layer, respectively [78]. This nitrogen was not readily available to plants but became available after harvest or in subsequent years [50]. According to some scholars, organic farming did not allow the release of nutrients when they were actually required by the plants [2]. Furthermore, the losses of nitrogen as nitrate with leaching were greater in organic farming than in conventional agriculture [2]. However, organic systems could mitigate climate change with a reduction in nitrogen gas emissions and carbon sequestration in the soil. Another advantage is that crop yields were usually equal or greater than those obtained with conventional agriculture [2].

\subsection{Cover Crops, Green Manures and Catch Crops}

Cover crops, green manures, and catch crops are also defined as Agro-ecological service crops (ASCs) [81]. ASCs bring numerous benefits to agriculture (Figure 1). They suppress weeds, increase the organic substance of the soil, slow down the leaching of nitrogen and improve the structure of the soil. They achieve this goal in both non-organic systems [82] and organic ones $[57,83,84]$. A reduction from 133 to $6 \mathrm{~kg} \mathrm{~N} \mathrm{ha}^{-1}(-95 \%)$ in nitrate leaching was shown in a potato crop grown on soil previously cultivated with grain legume, while a reduction in nitrate leaching from 213 to $17 \mathrm{~kg} \mathrm{~N} \mathrm{ha}^{-1}(-92 \%)$ was recorded when potato cultivation was cultivated after green manure [57]. The different ASCs can have different effects on the accumulation of mineral nitrogen in the soil. Cereal crops consume nitrogen $[83,85]$, while legumes fix nitrogen and make it available for subsequent crops [81]. The simultaneous use of cereals and legumes could reduce both the consumption of nitrogen fertilizers and nitrogen leaching [83]. 
ASCs are mowed and deposited on the ground or mowed and completely buried in the ground (with tillage). Another way to incorporate the ASCs is the use of roller-crimping, by which the ASC crop is not collected, but is only crushed to the ground, creating a mulch film made from vegetable biomass. In no-tillage organic systems, where herbicides are not allowed, the use of ASCs represents a very useful practice for suppressing weeds [86,87]. The benefits of using the roller-crimper are also economic ones, since it reduces the labor, and the energy required to uproot crops $[87,88]$.

Hefner et al. [81] compared the full incorporation and roller crimping techniques of legume and cereal ASCs (pea, pea/cereal mixtures, and cereals) to understand nitrogen turnover in soil and in organically cultivated cabbage plants in three regions of Northern and Eastern Europe, Estonia, Denmark, and Belgium, considering two cultivation cycles. The authors showed that ASCs reduced N availability for cabbage plants from $37 \%$ to $73 \%$, compared to bare soil, in particular with cereals. Higher availability of mineral nitrogen in the soil occurred with the full incorporation completed in April and May rather than with roller-crimping carried out in May and June. The lowest cabbage yields were obtained after roller-crimping rather than full incorporation or bare soil. However, with both full incorporation and roller-crimping, no mineral nitrogen losses were shown in the soil deep layers.

The effects of cover crops (CCs) on crop production depend on soil type, climatic conditions, and plant species used [89-91]. For example, it has been shown that Secale cereale L. (cereal rye) used as CC reduced the leaching of nitrate in the soil [62]. The use of Vicia villosa Roth (hairy vetch) as CC reduced the content of organic C and N, compared to treatments without CC. Instead, the mixed-use of Secale cereale L. and Vicia villosa Roth increased the content of organic $\mathrm{C}$ and $\mathrm{N}$.

Singh et al. [91] analyzed three crop rotations, corn + cereal rye + soybean + hairy vetch (CRSHV), corn + cereal rye + soybean + oat-radish (CRSOR), and corn-soybean rotation without winter CC (CS), and two tillage systems (conventional tillage (CT) and no tillage (NT)). Each crop rotation lasted two years. In tillage treatment, plant residues were incorporated in the soil, unlike non-tillage treatment. The water extractable nitrogen (WEN) and $\mathrm{N}$ total reduced with depth regardless of the type of rotation and tillage systems. The presence of cereal in both CCs reduced the WEN in the soil (by 1-2 kg ha-1), compared to the rotation without CC. In the two rotations with CCs (CRSHV and CRSOR), WEN was lower than in CS without CC. This result may be due to the higher $\mathrm{N}$ absorption of cereal rye in the two rotations, and the higher $\mathrm{C} / \mathrm{N}$ ratio in the two rotations compared to CS without CC [91]. Hairy vetch had a C/N of 10:1, in oats + radish it was 20:1, and weeds in CS had a C/N ratio of 22:1. Therefore in the presence of hairy vetch, there was a faster decomposition of residues and $\mathrm{N}$ was easily taken from corn to grow [91].

\subsection{Management Intensive Grazing}

Management intensive grazing (MIG) is livestock graze for about $24 \mathrm{~h}$, which is beneficial for the health of the animals and for reducing the costs for feeding. Moreover, it fertilizes the soil and increases productivity [92,93]. It is widely used in North Eastern United States and in many other countries with forage-based systems as in South America (Argentina, Brazil, etc.), for the production of organic milk [94]. Furthermore, according to many scholars, it fights climate change through soil carbon sequestration as it increases $C$ inputs into soil [95-98]. However, it appears that MIG systems contribute to a strong release of $\mathrm{N}_{2} \mathrm{O}$ into the atmosphere [99-101]. This happens because in soil nitrogen follows the biogeochemical cycle of carbon, and as the carbon accumulates, the substrate available for the microorganisms that release $\mathrm{N}_{2}$ Ois created. The increase in microbial activity, following the continuous organic inputs, consumes oxygen and creates anaerobic micro areas where the activity of microorganisms that produce $\mathrm{N}_{2} \mathrm{O}$ is created. Some studies, however, oppose the idea that the $\mathrm{C}$ sequestration in the soil favors the release of $\mathrm{N}_{2} \mathrm{O}$. The different relationship between $\mathrm{C}$ sequestration and release of $\mathrm{N}_{2} \mathrm{O}$ depends on several factors, including the type of $\mathrm{C}$ inputs, climatic conditions, soil characteristics, and agricultural 
practices [102] (Figure 1). Contosta et al. [92], examined the soil C content of an organic pasture, in three states of the northeastern United States where direct and fresh manure was the nitrogen input in order to find the relationship between MIG practice, soil C sequestration, and $\mathrm{N}_{2} \mathrm{O}$ release. The authors found that MIG practice increased both total $\mathrm{C}$ (\%) $(0-15 \mathrm{~cm})$ and total $\mathrm{N}\left(\mathrm{t} \mathrm{N} \mathrm{ha}^{-1}\right)$ in soil $(0-50 \mathrm{~cm})$, whereas the $\mathrm{C} / \mathrm{N}$ ratio was reduced, compared to cultivation hay, used as control. After two years of studies, the authors also reported a $33 \%$ increase in $\mathrm{N}_{2} \mathrm{O}$ in grazed fields and compared to hayed fields. They evaluated the activity of two nitrogen-degrading enzymes, $\mathrm{N}$-acetyl-glucosaminidase and leucine aminopeptidase and they showed a higher trend of their activity in grazed fields, with a mean value of 3.33 and $2.53 \mathrm{pmol} \mathrm{g}$ dry soil ${ }^{-1} \mathrm{~min}^{-1}$, respectively. Net nitrification was also greater in grazed fields, with a mean value of $6.26 \mu \mathrm{g} \mathrm{NO}_{3}{ }^{-} \mathrm{N} \mathrm{g}$ dry soil ${ }^{-1}$ day $^{-1}$.

\section{Genes Involved in Nitrogen Transport in Plants}

Some genetic approaches to improve crops yield are aimed at the identification and expression of genes involved in nitrogen uptake [24,103]. Nitrogen enters plants mainly in the form of nitrate and ammonium and can be transported through a low affinity transport system (LATS) or a high affinity transport system (HATS). LATS is active if the nitrogen concentration in the solution around the roots is greater than $1 \mathrm{mM}$. On the other hand, HATS is active if the external nitrogen concentration is less than $1 \mathrm{mM}[24,104]$.

From studies carried out on Arabidopsis, four families of genes coding for nitrogen transporters have been identified: $\mathrm{NO}_{3}$ transporter1/peptide (NRT1 or NPF, 53 members; [24]), $\mathrm{NO}_{3}$ transporter 2 (NRT2, seven members), the chloride channel (CLC, seven members), and slow anion channel associated 1 homologue (SLAC/SLAH, five members) $[5,24,105]$ (Table 1) (Figure 2).

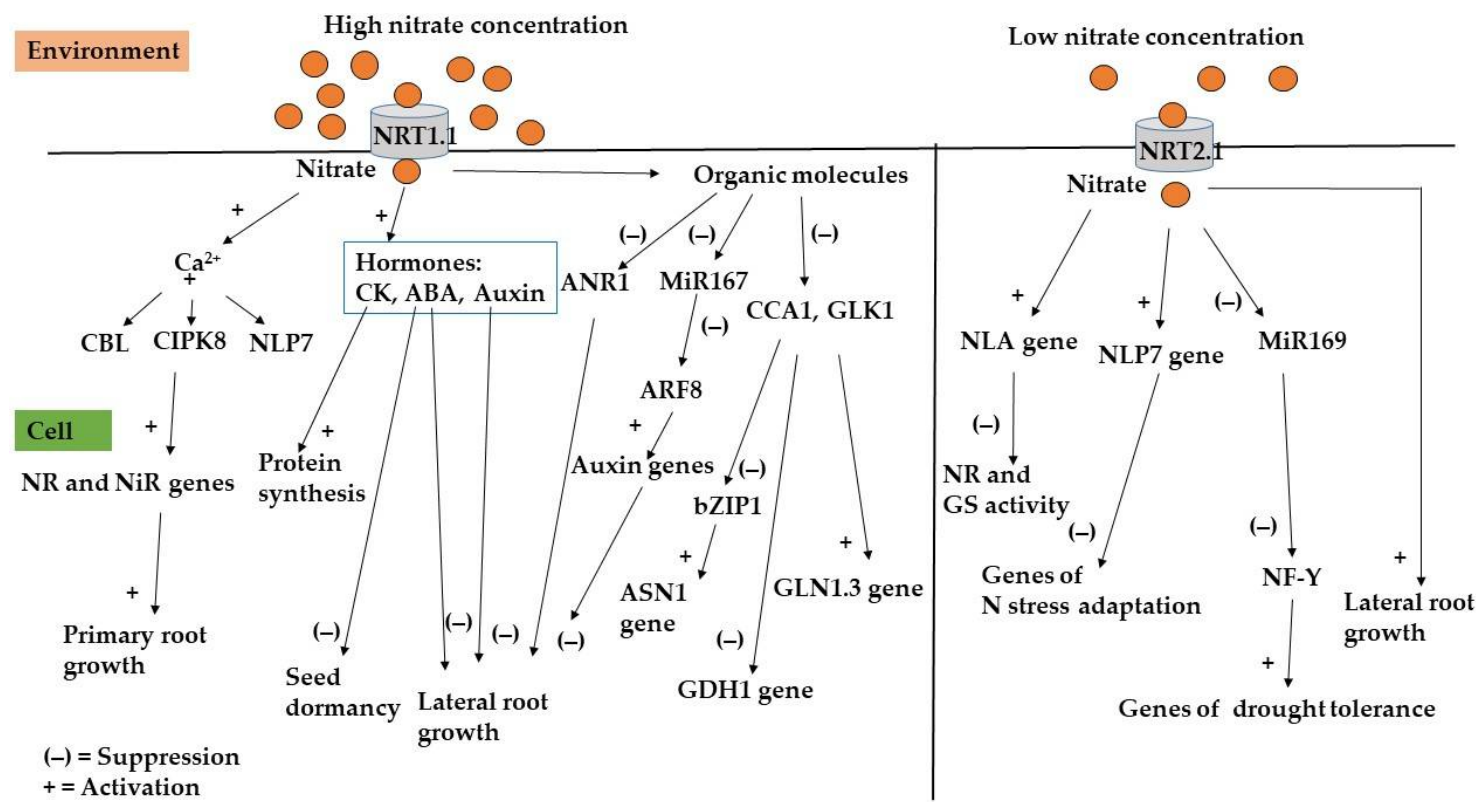

Figure 2. A schematic presentation of the interactions of the main genes involved in nitrogen transport in plants.

Plant aquaporins (AQPs) are intrinsic proteins that form channels across plasma membranes and through which water and anions, such as nitrate, may pass [106]. The role of aquaporins in nitrogen absorption has been demonstrated by the different expressions of the $A Q P$ genes concerning the availability of nitrogen in the external environment. AtTIP1; 2, AtTIP2; 1, and AtTIP4; 1 genes encoding aquaporins in Arabidopsis, were found overexpressed under conditions of reduced nitrogen concentration outside the plant [24].

Other genes involved in nitrogen transport are ZmPIP1; $5 b$ which is involved in water and urea transport in corn roots [107]; AtTIP2; 3 which is involved in ammonium transport 
in vacuoles in Arabidopsis plants [24]. Moreover, PtdPIP1; 2 and PtdSIP1; 2 belong to the aquaporin family in Populus trichocarpa [24].

Genetic studies on Arabidopsis revealed the role of NRT1.1 and NRT2.1 not only as nitrate transporters, but also as signal transmitters to genes that are involved in changing the root architecture in response to external nitrate concentration $[108,109]$. In particular, if the external concentration of nitrate is high: the nitrate enters the cell through NRT1.1 and it stimulates calcium accumulation. The calcineurin B-like protein perceives the changes in intracellular calcium concentration and activates the enzymes CBL, CIPK8, and the transcription factor NLP7. This cascade of interactions activates nitrate reductase and nitrite reductase genes, and the genes involved in the absorption of nitrate $[110,111]$. The primary root growth genes are also activated in this cascade (Figure 2).

Table 1. Genes involved in $\mathrm{N}$ assimilation.

\begin{tabular}{|c|c|c|c|}
\hline Gene & Function & Species & References \\
\hline NRT1 or NPF, (53 members) & Low affinity of nitrate transport & Arabidopsis & {$[24]$} \\
\hline NRT2 (seven members) & High affinity of nitrate transport & Arabidopsis & {$[24]$} \\
\hline CLC (seven members) & Chlorine and nitrate transport & Arabidopsis & {$[24]$} \\
\hline$S L A C / S L A H$, five members & Nitrate transport & Arabidopsis & {$[24]$} \\
\hline AtTIP1;2, AtTIP2;1, AtTIP $4 ; 1$ & Synthesis of aquoporins & Arabidopsis & {$[24]$} \\
\hline AtTIP2; 3 & Ammonium transport in vacuoles & Arabidopsis & {$[24]$} \\
\hline$Z m P I P 1 ; 5 b$ & $\begin{array}{l}\text { Water and urea transport in } \\
\text { corn roots }\end{array}$ & Corn & {$[107]$} \\
\hline PtdPIP1; 2 e PtdSIP1; 2 & $\begin{array}{l}\text { Water and urea transport in } \\
\text { corn roots }\end{array}$ & Populus trichocarpa & {$[24]$} \\
\hline$N L A$ & $\begin{array}{l}\text { Reduction of nitrate reductase and } \\
\text { glutamine synthetase activity }\end{array}$ & Arabidopsis & {$[112,113]$} \\
\hline NLP7 & Inhibition of NLA gene & Arabidopsis & {$[112,113]$} \\
\hline CYP707A2 & Inhibition of lateral roots growth & Arabidopsis & {$[111]$} \\
\hline IPT3 & Synthesis of cytokinins & Arabidopsis & [111] \\
\hline ASN1 & $\begin{array}{l}\text { Activated by the transcription } \\
\text { factor bZIP1, encoding } \\
\text { for asparaginesynthetase }\end{array}$ & Arabidopsis & [111] \\
\hline GLN1.3 & $\begin{array}{l}\text { Activated by the transcription } \\
\text { factor CCA1, encoding for } \\
\text { glutamine synthetase }\end{array}$ & Arabidopsis & {$[111]$} \\
\hline GDH1 & $\begin{array}{c}\text { Synthesis of } \\
\text { glutamate dehydrogenase }\end{array}$ & Arabidopsis & [111] \\
\hline HvNiR1 & Synthesis of nitrite reductase & Barley & {$[104]$} \\
\hline HvGS1_1 & $\begin{array}{l}\text { Synthesis of cytoplasmic } \\
\text { glutamine synthetase }\end{array}$ & Barley & {$[104]$} \\
\hline$H v G S 2$ & $\begin{array}{c}\text { Synthesis of } \\
\text { chloroplasticglutamine synthetase }\end{array}$ & Barley & {$[104]$} \\
\hline HvGLU2 & $\begin{array}{l}\text { Synthesis of ferredoxin-dependent } \\
\text { glutamate synthase }\end{array}$ & Barley & {$[104]$} \\
\hline HvASN1, & Synthesis of asparagine synthetase & Barley & {$[104]$} \\
\hline $\begin{array}{c}\text { HvNRT2.2, HvNRT2.3, } \\
\text { HvNRT3.1, } \\
\text { HvNRT3.1 }\end{array}$ & High affinity of nitrate transport & Barley & {$[104]$} \\
\hline HvNIA1, HvNIA2, & Synthesis of nitrate reductase & Barley & {$[104]$} \\
\hline BnaCLCs & $\begin{array}{l}\text { Genes family involved in the } \\
\text { nitrate transport in vacuoles }\end{array}$ & Brassica Napus L. & {$[8]$} \\
\hline OsDOF18 & $\begin{array}{c}\text { Synthesis of transcription factors } \\
\text { that activate genes for } \\
\text { ammonium absorption }\end{array}$ & Rice & {$[8]$} \\
\hline
\end{tabular}


Under conditions of low nitrate concentration, NRT1.1 is phosphorylated on the amino acid Thr101 by CIPK23 (calcineurin B-like protein-interacting kinase 23) and the following biochemical changes are observed in cells: (i) nitrate activates the genes involved in the adaptation to nitrogen stress through the activation of the transcription factors NLP7 and the NLA gene [112-114]. NLA gene works by reducing the activity of nitrate reductase and GS. NLP7 gene, which codes for nodule inception like 7 protein, was found to inhibit the plant's adaptation to stress derived from low nitrogen concentrations, thus counteracting the activity of NLA [114]; (ii) nitrate can regulate drought tolerance through the repression of mi169 and the transcription factor NFY [115]; (iii) nitrate can act directly by activating lateral root growth [111] (Figure 2).

Micro RNAs are small non-coding RNAs that regulate the genes involved in growth, development, and adaptation to abiotic and biotic stresses, both in plants and animals [116]. Studies in Arabidopsis have shown that certain miRNAs can be regulated by the availability of external nitrate [117]. MiR167, together with auxin-responsive factor ARF8, activates the genes that code for auxins and thereby trigger lateral root formation, or block lateral root formation in the presence of high external nitrate [118]. Conditions of low external nitrate intake were found to repress miR398 and miR169. MiR169 repression is involved in the transmission of external nitrogen depletion between shoots and roots [119] (Figure 2).

The effect of nitrate on lateral root growth also involves hormones. Auxin has a wide range of activities that take place in shoots and roots. For example, Arabidopsis plants transferred from a medium with high nitrate concentration to low nitrate concentration, increased the auxin content [111]. Their activity was found to inhibit lateral root growth in the presence of high external nitrate [111]. Nitrate can also regulate the genes that synthesize auxins through the transcription factor ARF8 [117,118]. Abscisic acid, activated by a high concentration of nitrate in the cell, regulates the dormancy of seeds, through the CYP707A2 gene, and also inhibits the growth of lateral roots. The IPT3 gene in Arabidopsis is involved in the synthesis of cytokinins and is activated by high concentrations of nitrate [111]. Cytokinins pass nitrogen levels in the roots to the shoots and their activity is inhibited by NRT2.1 [111].

The organic molecules, originating from the reduction of nitrate to ammonium in the cell, suppress the growth of lateral roots by inhibiting the transcription factor ANR1 [111]. They induce the expression of auxin genes through the reduction of the transcription factor ARF8 and miRNA167.

Genetic studies on Arabidopsis have revealed two transcription factors, Circadian Clock Associated-1 (CCA1), and the golden 2-like transcription factor 1 (GLK1), which activate the gene that encodes Glutamine synthetase 1.3 (GLN1.3) and inhibit the gene of Glutamate dehydrogenase 1 (GDH1) and bZIP1 transcription factor which was predicted to positively affect the expression of Asparagine synthetase 1 (ASN1) [111] (Figure 2).

Kollaricsné Horváth et al. [120] examined the response of five potato cultivars (White Lady, Katica, Hópehely, Chipke, and S440) to three nitrogen levels (7.5, 3 and $0.75 \mathrm{mmol}$ of nitrate), evaluating the expression of genes which synthesize nitrate-reductase (NR) that reduces nitrate to nitrite, nitrite-reductase (NiR) that reduces nitrite to ammonium, asparagine synthase (AS) that catalyzes the synthesis of asparagine from glutamate and finally the gene that encodes the ammonium transporter (AMT). The results showed that the expression of all the enzymes examined was different according to the cultivar. NR did not change its expression based on different nitrogen levels. The expression of AMT was different at different nitrogen doses. Instead, Nir and AS expressions were similar at medium and high doses of nitrogen but changed their activity under a low nitrogen supply.

Chen et al. [104] examined two cultivars of barley (Hordeum vulgare L.), BI-04 and BI-45, which were, respectively, tolerant and sensitive to low nitrogen and were cultivated with a reduced level of nitrogen $\left(0.24 \mathrm{mM} \mathrm{NH}_{4} \mathrm{NO}_{3}\right)$ in the nutrient solution. The results of their work showed that the genes encoding nitrite reductase (HvNIR1), chloroplastic glutamine synthetase (HvGS2), and ferredoxin-dependent glutamate synthase (HvGLU2), were expressed only in the shoots of tolerant species, while HvGLU2 and HvGS2 were 
expressed only in the roots of the tolerant cultivars. Both cultivars had a lower expression of the gene encoding asparagine synthetase (HvASN1).

Yang et al. [121] examined the gene expression of two cultivars of Sorghum bicolor (L.) Moench (Keza15, tolerant to low nitrogen supplies, and Suiza7 sensitive to low external nitrogen concentrations), grown in hydroponics and subjected to nitrogen stress $(0 \mathrm{mmol} / \mathrm{L})$, compared to control plants which were grown with $4 \mathrm{mmol} / \mathrm{L}$ of $\mathrm{Ca}\left(\mathrm{NO}_{3}\right)_{2}$ in the nutrient solution. Genes involved in the synthesis of high-affinity nitrate transporters (NRT2.4, NRT3.1, and NRT4.5) were over-expressed in the KZ15 cultivar. The genes examined were considered by authors as candidates for increasing tolerance to low nitrogen stress. Other genes, over-expressed in KZ15 under stress conditions, encoded various transcription factor families (WRKY, MYB, bHLH, ethylene-responsive factor, and nuclear factor-Y or NF-Y). In both cultivars, under nitrogen stress conditions, there was an over-expression of glutathione metabolism genes.

Liao et al. [8] demonstrated the involvement and different regulation of BnaCLC genes (a family of genes encoding Chloride Channel; CLC) in Brassica napus, based on external nitrate replenishment. CLCs are channels that transport nitrate and chlorine at vacuoles level [8]. The authors identified the CLCa-3 gene as fundamental in the transport of nitrate in vacuoles in B.napus, since its expression was induced up to 20 times in shoots and 6 times in roots, following the nitrate replenishment.

\section{Accumulation of Nitrate in Rocket Plants: Effect of Biological Activity, Fertilization, and Agricultural Practices}

Vegetables make a high contribution to the intake of nitrates in human diet on a daily basis [122]. If nitrate is absorbed without being reduced, it accumulates in plant cells [123]. Many factors influence this accumulation, such as the physical and chemical characteristics of soil $[123,124]$, the plant species [123,125-128], the fertilization regime [129,130], and the growing season and climatic conditions [131]. Since nitrate accumulates mainly in the leaves, leafy vegetables are considered the richest sources of nitrates among vegetables [132]. Furthermore, they have rapid growth, so they can quickly absorb high amounts of nitrates $[128,133,134]$. In Mediterranean countries, characterized by a temperate and sub-tropical climate and with high intensity of light, a high activity of nitrate reductase is allowed and therefore a reduced concentration of nitrates in leafy vegetables, both grown in open fields and greenhouses, should be expected [135].

The positive aspects of nitrates on human health should also be considered. Dietary nitrate generates nitric oxide ( $\mathrm{NO})$, which has positive effects on the vascular system, blood pressure regulation, atherosclerosis, and ischemia [136,137], muscle activity increase [138], and triglycerides reduction [139].

However, nitrates and nitrites are considered carcinogenic compounds for humans by the International Agency for Research on Cancer [140], since they react with amines and amides, forming N-nitrous compounds, which are carcinogens [122,140]. High nitrate levels have also been associated with diseases, such as hypothyroidism and methemoglobinemia [122,141]. Due to these results, the World Health Organization (WHO) and the European Food Safety Authority [142] made it necessary to establish safety limits for the intake of nitrate from food and water, establishing the acceptable daily intake (ADI) of $3.7 \mathrm{mg} / \mathrm{kg}$ body weight/day [135]. To achieve this goal, the European Community has established maximum limits for the nitrate content in spinach, lettuce, arugula, and cereals, which are considered as nitrate accumulators [135]. The European regulation has established the highest limits of nitrate content for rocket at $7000 \mathrm{mg} / \mathrm{kg}$ if grown in winter (from 1 October to $31 \mathrm{March}$ ), and at $6000 \mathrm{mg} / \mathrm{kg}$ if grown in summer (from 1 April to 30 September). It has been observed that the maximum limits of nitrate in plants, established by the European Community, can be exceeded, in particular for rocket and spinach, when nitrogen fertilization rates exceed $200 \mathrm{~kg} / \mathrm{ha}$ [135]. The consumption of leafy vegetables with high nitrate content becomes risky for people who eat only vegetables, such as vegetarians and vegans. 
Leon and Luzardo [143] determined the nitrate level in watercress and chard, which are rich in nitrate, but are non-regulated for nitrate content by European Regulation, and in different varieties of lettuce (romaine, iceberg, baby lettuce, 4 th range salads), arugula and spinach, all regulated, in the Canary Islands. The authors recorded the highest nitrate values in rocket plants $(3144.2 \mathrm{mg} / \mathrm{kg}$ ) compared to other vegetables. However, these values were lower than those reported by other authors [132]. Therefore, the authors linked these results to the dry and sunny climate of the Canary Islands (average annual $\mathrm{T}$ in the range $18-24{ }^{\circ} \mathrm{C}$, and a high number of sunshine hours both in winter and in summer) [143].

Light is essential for photosynthesis, which provides the electrons needed to reduce nitrates through nitrate reductase [144]. Photosynthesis also provides the carbonaceous skeletons for the assimilation of ammonium ions. On the other hand, studies carried out under controlled conditions with low irradiance have shown the reduced activity of nitrate reductase and the consequent accumulation of nitrates in spinach and lettuce leaves [135].

The effect of nitrogen fertilization on nitrate accumulation has been extensively studied under controlled conditions, such as cultivation in pots [145,146], or in soilless systems [147]. However, little is reported for field crops and for the effect of application time under field growing conditions [135].

As for cultivation practices, generally in the literature conventional practices are compared with organic ones. However, the results are contradictory, so that the nitrate content obtained with one agricultural practice can be similar, higher or lower than that obtained with the compared practice $[130,148,149]$. The reason for the contradictory results lies in the type of fertilizers used, the plant species, and the growing site [130]. According to many authors, organic fertilization, characterized by the slow release of nitrogen forms available to plants, involves a reduced content of nitrate in plants, compared to mineral fertilizers, while the order of nitrate content in relation to the cultivation system is hydroponic-conventional-organic [135]. Moreover, Kyriacou et al. [135] found that by applying nitrogen, organic or inorganic in base-dressing mode, and at doses of $100 \mathrm{~kg} \mathrm{~N} \mathrm{ha}^{-1}$, the nitrate levels did not exceed the limits established by the EC.

\section{Useful Approaches to Mitigate Nitrogen Losses}

The integrated approach system (IPS) is based on the interconnection between different agricultural systems and the integrated use of plant and animal residues, with minimal nitrogen inputs [2]. This is well represented by the exchange of manure and vegetable residues for livestock, between farmers and shepherds of the same territory. This approach is widely applied in Nigeria and the Republic of Benin, East Africa [2]. Integrated croplivestock systems (ICLS) are systems in which livestock and crops are kept together in the same area. In such systems, animals feed on a crop, returning nutrients to the soil through urine and manure [150]. In this way, soil organic matter increases, as well as the microbial diversity and their activity. Such systems guarantee nutrient cycle and production for a long time, without resorting to external nitrogen inputs, thus minimizing the impact of inorganic fertilizers on the environment. Furthermore, herbs, which cannot be eaten by humans, are transformed into food (meat, milk) by ruminants. Farias et al. [150] compared a conventional cropping system (soybean crop succeeded by a non-grazed Italian ryegrass cover crop fertilized with N, P, K), and an ICLS (soybean-Italian ryegrass rotation grazed by sheep), to test their effect on herbage and animal production. The authors recorded a greater total herbage production and greater stocking rates in the ICLS system, compared to the conventional cropping system. The positive effect of ICLS was also observed in the greater soybean yield [150].

One approach to mitigate the release of ammonia from the soil is represented by Farm Best Available Techniques (BATs), such as the burying of fertilizers, or the application of fertilizers with urease inhibitors [151]. If the animal slurry is used, nitrification inhibitors can be also added to the soil [152]. To reduce $\mathrm{N}_{2} \mathrm{O}$ losses, soil $\mathrm{pH}$ can be increased by lime addition, while avoiding anaerobic conditions with suitable soil irrigation, or by reducing 
the passage of animals that could compact the soil thus creating a condition of anaerobiosis, could also help to this matter $[151,153]$.

Urease inhibitors are N- (n-butyl) thiophosphoric triamide (NBPT) and phenylphosphorodiamidate, while nitrification inhibitors are dicyandiamide (DCD) and 3,4-dimethyl pyrazole phosphate (DMPP). The application of NBPT to urea resulted in a $42 \%$ reduction in $\mathrm{NH}_{3}$ from sunflower cultivation in Spain [2]. Similar results were found in wheat crops in Australia [2] and cereals in the UK [2]. Similarly, urea associated with DMPP and DCD reduced the release of $\mathrm{N}_{2} \mathrm{O}$ by about $70 \%$ from American soils [154]. In anoxic conditions with the continuous presence of water, as in the case of rice fields, nitrification and denitrification contribute highly to the loss of nitrogen $\left(\mathrm{N}_{2} \mathrm{O}\right.$ and $\left.\mathrm{NH}_{3}\right)$ [19]. In this context, the use of urea granules $(0.7 \mathrm{~g})$, buried deep in the soil, was used and this technique was useful in terms of rice yield, and in reducing nitrogen losses $[155,156]$. Similarly, the deep burying of mineral and organic fertilizers attenuated the volatilization of ammonia in corn crops, compared to the superficial spreading of fertilizers [157].

The wastewater in livestock farms is rich in nitrogen, due to the feces and urine of the animals. To reduce ammonia and $\mathrm{N}_{2} \mathrm{O}$ emissions from these sources, it is possible to resort to the introduction of microalgae, which use these compounds for their growth [158] and convert inorganic nitrogen into organic compounds [159]. The introduction of Chlorella sp. [2] and Gracilaria birdiae significantly reduced nitrogen oxide emissions in wastewater [160].

From the point of view of genetic engineering, scientists have tried to modify cereals towards nitrogen fixation. Nod factors (legume-rhizobia symbiosis) and Myc factors (cerealarbuscular mycorrhizal fungal symbiosis) are similar, so that it would be possible to induce expression of Nod genes in cereals [2]. On the other hand, strong communication with signals was observed between cereals and microbes of the rhizosphere [161,162]. However, these studies are still relegated to the laboratory and are not extrapolated to field conditions.

Site-specific nutrient management strategy (SSNM) is a strategy based on the analysis of a specific crop, its nutritional needs, and the maximum use of available resources, to reach the optimal dose of nitrogen for crop [2].

In the work by Candido et al. [163], the activity of the biostimulant Azoxystrobin (Ortiva ${ }^{\circledR}$, Syngenta) on the yield, quality, and NUE of rocket plants, grown at two nitrogen levels (40 and $140 \mathrm{~kg} \mathrm{ha}^{-1}$, in the form of ammonium nitrate), was evaluated. In plants treated with biostimulants, nitrate content did not vary compared to the control plants (plants treated with the two nitrogen levels, but without biostimulant). However, the presence of biostimulant improved rocket quality in terms of higher content of pigments (chlorophyll and carotenoids), phenols, and antioxidant activity. Therefore, the biostimulant application could be an eco-sustainable alternative to the fertilizer treatment in rocket plants.

\section{Conclusions}

The use of nitrogen fertilizers in crop production was a significant breakthrough that made it possible to increase yields and food production. However, despite the positive effects of nitrogen fertilizer on crops its irrational use has made it a threat to food security and the environment around the world. These negative effects of nitrogen need to be alleviated with sustainable cultivation practices. One solution is the search and breeding for genotypes tolerant to nitrogen stress, as well as the increase of the NUE of crops through rational fertilization regimes and reduced nitrogen leaching. Unfortunately, climate change, also linked to nitrogen losses in the environment seems unstoppable and nitrogen fertilization management needs urgent measures to be taken. The COVID-19 pandemic has shown that a reduction in greenhouse gases can be achieved if human activities slow down. However, since it is not possible to stop human activities for long periods, definite decisions to curb pollution, resulting from the uncontrolled use of nitrogen, should be taken on a global and national level. 
Author Contributions: Conceptualization, M.G. and Y.R.; writing-original draft preparation, M.G., S.A.P. and Y.R.; writing-review and editing, M.G., S.A.P. and Y.R.; visualization, M.G., S.A.P. and Y.R.; supervision, M.G., S.A.P. and Y.R.; project administration, Y.R.; funding acquisition, M.G. and Y.R. All authors have read and agreed to the published version of the manuscript.

Funding: This research received no external funding.

Institutional Review Board Statement: Not applicable.

Informed Consent Statement: Not applicable.

Data Availability Statement: Not applicable.

Conflicts of Interest: The authors declare no conflict of interest.

\section{References}

1. Grafton, R.Q.; Daugbjerg, C.; Qureshi, M.E. Towards food security by 2050. Food Secur. 2015, 7, 179-183. [CrossRef]

2. Mahmud, K.; Panday, D.; Mergoum, A.; Missaoui, A. Nitrogen losses and potential mitigation strategies for a sustainable agroecosystem. Sustainability 2021, 13, 2400. [CrossRef]

3. Rodriguez, A.; Sanders, I.R. The role of community and population ecology in applying mycorrhizal fungi for improved food security. ISME J. 2015, 9, 1053-1061. [CrossRef]

4. FAO. 2015. Available online: http:/ / faostat.fao.org (accessed on 27 September 2021).

5. Pathak, H.; Jain, N.; Bhatia, A.; Kumar, A.; Chatterjee, D. Improved nitrogen management: A key to climate change adaptation and mitigation. Indian J. Fertil. 2016, 12, 151-162.

6. Houlton, B.Z.; Almaraz, M.; Aneja, V.; Austin, A.T.; Bai, E.; Cassman, K.G.; Compton, J.E.; Davidson, E.A.; Erisman, J.W.; Galloway, J.N. A world of cobenefits: Solving the global nitrogen challenge. Earth's Future 2019, 7, 865-872. [CrossRef] [PubMed]

7. Xu, P.; Chen, A.; Houlton, B.Z.; Zeng, Z.; Wei, S.; Zhao, C.; Lu, H.; Liao, Y.; Zheng, Z.; Luan, S. Spatial variation of reactive nitrogen emissions from China's croplands codetermined by regional urbanization and its feedback to global climate change. Geophys. Res. Lett. 2020, 47, e2019GL086551. [CrossRef]

8. Liao, Q.; Zhou, T.; Yao, J.-Y.; Han, Q.-F.; Song, H.-X.; Guan, C.-Y.; Hua, Y.-P.; Zhang, Z.H. Genome-scale characterization of the vacuole nitrate transporter chloride channel (CLC) genes and their transcriptional responses to diverse nutrient stresses in allotetraploid rapeseed. PLOS ONE 2018, 13, e0208648. [CrossRef]

9. Fesenfeld, L.P.; Schmidt, T.S.; Schrode, A. Climate policy for short-and long-lived pollutants. Nat. Clim. Chang. 2018, 8, 933-936. [CrossRef]

10. Liu, M.; Huang, X.; Song, Y.; Tang, J.; Cao, J.; Zhang, X.; Zhang, Q.; Wang, S.; Xu, T.; Kang, L. Ammonia emission control in China would mitigate haze pollution and nitrogen deposition, but worsen acid rain. Proc. Natl. Acad. Sci. USA 2019, 116, 7760-7765. [CrossRef]

11. Ladha, J.K.; Tirol-Padre, A.; Reddy, C.K.; Cassman, K.G.; Verma, S.; Powlson, D.S.; van Kessel, C.; Richter, D.d.B.; Chakraborty, D.; Pathak, H. Global nitrogen-budgets-in-cereals-a-50-year-assessment. Sci. Rep. 2016, 6, 19355. [CrossRef]

12. Gao, W.; Yang, H.; Kou, L.; Li, S. Effects of nitrogen deposition and fertilization on $\mathrm{N}$ transformations in forest soils: A review. J. Soils Sediments 2015, 15, 863-879. [CrossRef]

13. Venterea, R.T.; Halvorson, A.D.; Kitchen, N.; Liebig, M.A.; Cavigelli, M.A.; Grosso, S.J.D.; Motavalli, P.P.; Nelson, K.A.; Spokas, K.A.; Singh, B.P. Challenges and opportunities for mitigating nitrous oxide emissions from fertilized cropping systems. Front. Ecol. Environ. 2012, 10, 562-570. [CrossRef]

14. Hoben, J.; Gehl, R.; Millar, N.; Grace, P.; Robertson, G. Nonlinear nitrous oxide $\left(\mathrm{N}_{2} \mathrm{O}\right)$ response to nitrogen fertilizer in on-farm corn crops of the US Midwest. Glob. Chang. Biol. 2011, 17, 1140-1152. [CrossRef]

15. Shcherbak, I.; Millar, N.; Robertson, G.P. Global metaanalysis of the nonlinear response of soil nitrous oxide $\left(\mathrm{N}_{2} \mathrm{O}\right)$ emissions to fertilizer nitrogen. Proc. Natl. Acad. Sci. USA 2014, 111, 9199-9204. [CrossRef]

16. Huddell, A.M.; Galford, G.L.; Tully, K.L.; Crowley, C.; Palm, C.A.; Neill, C.; Hickman, J.E.; Menge, D.N. Meta-analysis on the potential for increasing nitrogen losses from intensifying tropical agriculture. Glob. Chang. Biol. 2020, 26, 1668-1680. [CrossRef] [PubMed]

17. IPCC. Climate Change 2014: Impacts, Adaptation, and Vulnerability Working Group II Contribution to the Fifth Assessment Report; Cambridge University Press: Cambridge, UK; New York, NY, USA, 2014.

18. Leach, A.M.; Galloway, J.N.; Bleeker, A.; Erisman, J.W.; Kohn, R.; Kitzes, J. A nitrogen footprint model to help consumers understand their role in nitrogen losses to the environment. Environ. Dev. 2012, 1, 40-66. [CrossRef]

19. Mohanty, S.; Swain, C.K.; Kumar, A.; Nayak, A. Nitrogen Footprint: A Useful Indicator of Agricultural Sustainability. In Nutrient Dynamics for Sustainable Crop Production; Springer: Singapore, 2020; pp. 135-156. [CrossRef]

20. Oita, A.; Nagano, I.; Matsuda, H. An improved methodology for calculating the nitrogen footprint of seafood. Ecol. Indic. 2016, 60,1091-1103. [CrossRef]

21. Galloway, J.N.; Winiwarter, W.; Leip, A.; Leach, A.M.; Bleeker, A.; Erisman, J.W. Nitrogen footprints: Past, present and future. Environ. Res. Lett. 2014, 9, 115003. [CrossRef] 
22. Shibata, H.; Cattaneo, L.R.; Leach, A.M.; Galloway, J.N. First approach to the japanese nitrogen footprint model to predict the loss of nitrogen to the environment. Environ. Res. Lett. 2014, 9, 115013. [CrossRef]

23. Dhar, A.R.; Oita, A.; Matsubae, K. The effect of religious dietary cultures on food nitrogen and phosphorus footprints: A case study of India. Nutrients 2021, 13, 1926. [CrossRef] [PubMed]

24. Nguyen, G.N.; Joshi, S.; Kant, S. Water availability and nitrogen use in plants: Effects, interaction, and underlying molecular mechanisms. Plant Macronutri. Use Effic. 2017, 233-243. [CrossRef]

25. Ren, B.; Wang, M.; Chen, Y.; Sun, G.; Li, Y.; Shen, Q.; Guo, S. Water absorption is affected by the nitrogen supply to rice plants. Plant Soil 2015, 396, 397-410. [CrossRef]

26. Lü, X.-T.; Dijkstra, F.A.; Kong, D.-L.; Wang, Z.-W.; Han, X.-G. Plant nitrogen uptake drives responses of productivity to nitrogen and water addition in a grassland. Sci. Rep. 2014, 4, 4817. [CrossRef]

27. Vadez, V. Root hydraulics: The forgotten side of roots in drought adaptation. Field Crop Res. 2014, 165, 15-24. [CrossRef]

28. Pandey, A.; Li, F.; Askegaard, M.; Olesena, J.E. Biological nitrogen fixation in three long-term organic and conventional arable crop rotation experiments in Denmark. Eur. J. Agron. 2017, 90, 87-95. [CrossRef]

29. Pandey, A.; Li, F.; Askegaard, M.; Rasmussen, I.A.; Olesen, J.E. Nitrogen balances in organic and conventional arable crop rotations and their relations to nitrogen yield and nitrate leaching losses. Agric. Ecosyst. Environ. 2018, 265, 350-362. [CrossRef]

30. Meng, L.; Zhang, A.; Wang, F.; Han, X.; Wang, D.; Li, S. Arbuscular mycorrhizal fungi and rhizobium facilitate nitrogen uptake and transfer in soybean/maize intercropping system. Front. Plant Sci. 2015, 6, 339. [CrossRef] [PubMed]

31. Andrews, M.; Raven, J.A.; Lea, P.J. Do plants need nitrate? The mechanisms by which nitrogen form affects plants. Ann. Appl. Biol. 2013, 163, 174-199. [CrossRef]

32. Chalk, P.M.; Ináciob, C.T.; Chena, D. An overview of contemporary advances in the usage of ${ }^{15} \mathrm{~N}$ natural abundance $\left(\delta^{15} \mathrm{~N}\right)$ as a tracer of agro-ecosystem N cycle processes that impact the environment. Agric. Ecosyst. Environ. 2019, 283, 106570. [CrossRef]

33. Mundepi, A.; Cabrera, M.; Norton, J.; Habteselassie, M. Ammonia oxidizers as biological health indicators of elevated Zn and Cu in poultry litter amended soil. Water Air Soil Pollut. 2019, 230, 239. [CrossRef]

34. Cassity-Duffey, K.; Cabrera, M.; Franklin, D.; Gaskin, J.; Kissel, D. Effect of soil texture on nitrogen mineralization from organic fertilizers in four common southeastern soils. Soil Sci. Soc. Am. J. 2020, 84, 534-542. [CrossRef]

35. Cameron, K.; Di, H.J.; Moir, J. Nitrogen losses from the soil/plant system: A review. Ann. Appl. Biol. 2013, 162, 145-173. [CrossRef]

36. Paulot, F.; Jacob, D.J.; Pinder, R.; Bash, J.; Travis, K.; Henze, D. Ammonia emissions in the United States, European Union, and China derived by high-resolution inversion of ammonium wet deposition data: Interpretation with a new agricultural emissions inventory (MASAGE_NH3). J. Geophys. Res. Atmos. 2014, 119, 4343-4364. [CrossRef]

37. Inácio, C.T.; Magalhães, A.M.T.; Souza, P.O.; Chalk, P.M.; Urquiaga, S. The relative isotopic abundance $\left(\delta^{13} \mathrm{C}, \delta^{15} \mathrm{~N}\right) \mathrm{during}$ composting of agricultural wastes in relation to compost quality and feedstock. Isot. Environ. Health Stud. 2018, 54, 185-195. [CrossRef]

38. Bowatte, G.; Erbas, B.; Lodge, C.J.; Knibbs, L.D.; Gurrin, L.C.; Marks, G.B.; Thomas, P.S.; Johns, D.P.; Giles, G.G.; Hui, J. Traffic related air pollution exposure over a 5-year period is associated with increased risk of asthma and poor lung function in middle age. Eur. Respir. J. 2017, 50, 1602357. [CrossRef] [PubMed]

39. Butterbach-Bahl, K.; Baggs, E.M.; Dannenmann, M.; Kiese, R.; Zechmeister-Boltenstern, S. Nitrous oxide emissions from soils: How well do we understand the processes and their controls? Philos. Trans. R. Soc. B Biol.Sci. 2013, 368, 20130122. [CrossRef]

40. Syakila, A.; Kroeze, C. The global nitrous oxide budget revisited. Greenh. Gas Meas. Manag. 2011, 1, 17-26. [CrossRef]

41. Sarabia, L.; Solorio, F.J.; Ramírez, L.; Ayala, A.; Aguilar, C.; Ku, J.; Almeida, C.; Cassador, R.; Alves, B.J.; Boddey, R.M. Improving the nitrogen cycling in livestock systems through silvopastoral systems. In Nutrient Dynamics for Sustainable Crop Production Springer: Singapore, 2020; pp. 189-213. [CrossRef]

42. Caranto, J.D.; Lancaster, K.M. Nitric oxide is an obligate bacterial nitrification intermediate produced by hydroxylamine oxidoreductase. Proc. Natl. Acad. Sci. USA 2017, 114, 8217-8222. [CrossRef]

43. Hu, H.-W.; Chen, D.; He, J.-Z. Microbial regulation of terrestrial nitrous oxide formation: Understanding the biological pathways for prediction of emission rates. FEMS Microbiol. Rev. 2015, 39, 729-749. [CrossRef]

44. Liu, S.; Han, P.; Hink, L.; Prosser, J.; Wagner, M.; Brüggemann, N. Abiotic conversion of extracellular $\mathrm{NH}_{2} \mathrm{OH}$ contributes to $\mathrm{N}_{2} \mathrm{O}$ emission during ammonia oxidation. Environ. Sci. Technol. 2017, 51, 13122-13132. [CrossRef]

45. Thangarajan, R.; Bolan, N.S.; Tian, G.L.; Naidu, R.; Kunhikrishnan, A. Role of organic amendment application on greenhouse gas emission from soil. Sci. Total Environ. 2013, 465, 72-96. [CrossRef] [PubMed]

46. Krauss, M.; Krause, H.M.; Spangler, S.; Kandeler, E.; Behrens, S.; Kappler, A.; Mäder, P.; Gattinger, A. Tillage system affects fertilizer-induced nitrous oxide emissions. Biol. Fert. Soils 2017, 53, 49-59. [CrossRef]

47. Li, X.; Sørensen, P.; Olesen, J.E.; Petersen, S.O. Evidence for denitrification as main source of $\mathrm{N}_{2} \mathrm{O}$ emission from residue-amended soil. Soil Biol. Biochem. 2016, 92, 153-160. [CrossRef]

48. Bakken, L.R.; Bergaust, L.; Liu, B.; Frostegård, A. Regulation of denitrification at the cellular level: A clue to the understanding of $\mathrm{N}_{2} \mathrm{O}$ emissions from soils. Philos. Trans. R. Soc. B 2012, 367, 1226-1234. [CrossRef]

49. Balaine, N.; Clough, T.J.; Beare, M.H.; Thomas, S.M.; Meenken, E.D.; Ross, J.G. Changes in relative gas diffusivity explain soil nitrous oxide flux dynamics. Soil Sci. Soc. Am. J. 2013, 77, 1496. [CrossRef] 
50. Hansen, S.; Frøseth, R.B.; Stenberg, M.; Stalenga, J.; Olesen, J.E.; Krauss, M.; Radzikowski, P.; Doltra, J.; Nadeem, S.; Torp, T.; et al. Reviews and syntheses: Review of causes and sources of $\mathrm{N} 2 \mathrm{O}$ emissions and NO3 leaching from organic arable crop rotations. Biogeosciences 2019, 16, 2795-2819. [CrossRef]

51. Skinner, C.; Gattinger, A.; Krauss, M.; Krause, H.-M.; Mayer, J.; van der Heijden, M.G.A.; Mäder, P. The impact of longterm organic farming on soil-derived greenhouse gas emissions. Sci. Rep. 2019, 9, 1702. [CrossRef]

52. Peyrard, C.; Mary, B.; Perrin, P.; Vericel, G.; Grehan, E.; Justes, E.; Leonard, J. $\mathrm{N}_{2} \mathrm{O}$ emissions of low input cropping systems as affected by legume and cover crops use. Agric. Ecosyst. Environ. 2016, 224, 145-156. [CrossRef]

53. Pugesgaard, S.; Petersen, S.O.; Chirinda, N.; Olesen, J.E. Crop residues as driver for $\mathrm{N}_{2} \mathrm{O}$ emissions from a sandy loam soil. Agric. Forest. Meteorol. 2017, 233, 45-54. [CrossRef]

54. Chen, H.H.; Li, X.C.; Hu, F.; Shi, W. Soil nitrous oxide emissions following crop residue addition: A meta-analysis. Glob. Chang. Biol. 2013, 19, 2956-2964. [CrossRef]

55. Li, X.; Petersen, S.O.; Sørensen, P.; Olesen, J.E. Effects of contrasting catch crops on nitrogen availability and nitrous oxide emissions in an organic cropping system. Agric. Ecosyst. Environ. 2015, 199, 382-393. [CrossRef]

56. Couto-Vázquez, A.; González-Prieto, S.J. Fate of ${ }^{15} \mathrm{~N}$-fertilizers in the soil-plant system of a forage rotation under conservation and plough tillage. Soil Tillage Res. 2016, 161, 10-18. [CrossRef]

57. De Notaris, C.; Rasmussen, J.; Sørensen, P.; Olesen, J.E. Nitrogen leaching: A crop rotation perspective on the effect of N surplus, field management and use of catch crops. Agric. Ecosyst. Environ. 2018, 55, 1-11. [CrossRef]

58. Brender, J.D.; Weyer, P.J.; Romitti, P.A.; Mohanty, B.P.; Shinde, M.U.; Vuong, A.M.; Sharkey, J.R.; Dwivedi, D.; Horel, S.A.; Kantamneni, J. Prenatal nitrate intake from drinking water and selected birth defects in offspring of participants in the national birth defects prevention study. Environ. Health Perspect. 2013, 121, 1083-1089. [CrossRef] [PubMed]

59. Santamaria, P. Nitrate in vegetables: Toxicity, content, intake and EC regulation. J. Sci. Food Agric. 2006, 86, 10-17. [CrossRef]

60. Gomes, M.A.F.; Barizon, R.R.M. Panorama da Contaminação Ambiental por Agrotóxicos e Nitrato de Origem Agrícola no Brasil: Cenário 1992/2011; Embrapa Meio Ambiente: Jaguariúna, Brazil, 2014.

61. de Barros Sylvestre, T.; Boscov Braos, L.; Batistella Filho, F.; Pessôa da Cruzb, M.C.; Ferreira, M.E. Mineral nitrogen fertilization effects on lettuce crop yield and nitrogen leaching. Sci. Hortic. 2019, 255, 153-160. [CrossRef]

62. Singh, G.; Gurpreet, K.; Karl, W.J.; Williard Jon, E. Schoonover. Cover crops and tillage effects on carbon-nitrogen pools: A lysimeter study. Vadose Zone J. 2021, 20, e20110. [CrossRef]

63. Zhang, W.; Liang, C.; Kao-Kniffin, J.; He, H.B.; Xie, H.T.; Zhang, H.; Zhang, X.D. Differentiating the mineralization dynamics of the originally present and newly synthesized amino acids in soil amended with available carbon and nitrogen substrates. Soil Biol. Biochem. 2015, 85, 162-169. [CrossRef]

64. Lu, C.; Chen, H.; Teng, Z.; Yuan, L.; Ma, J.; He, H.; Chen, X.; Zhang, X.; Shia, Y. Effects of N fertilization and maize straw on the dynamics of soil organic $\mathrm{N}$ and amino acid $\mathrm{N}$ derived from fertilizer $\mathrm{N}$ as indicated by 15N labeling. Geoderma 2018, 321, 118-126. [CrossRef]

65. Smith, C.J.; Chalk, P.M. The residual value of fertiliser $\mathrm{N}$ in crop sequences: An appraisal of 60 years of research using ${ }^{15} \mathrm{~N}$ tracer. Field Crop. Res. 2018, 217, 66-74. [CrossRef]

66. Willer, H.; Lernoud, J. The World of Organic Agriculture. Statistics Emerging Trends 2018; Research Institute of Organic Agriculture (FiBL), Frick and IFOAM-Organics International: Bonn, Germany, 2018.

67. Willer, H.; Schaack, D.; Lernoud, J. Organic farming and market development in Europe and the European Union. In The World of Organic Agriculture, Statistics and Emerging Trends; Willer, H., Lernoud, J., Eds.; Research Institute of Organic Agriculture (FiBL), Frick and IFOAM-Organics International: Bonn, Germany, 2018; pp. 218-255.

68. IFOAM: The Principles of Organic Agriculture. Available online: https://www.ifoam.bio/sites/default/files/poa_english_web. pdf (accessed on 17 June 2013).

69. McGee, J.A. Does certified organic farming reduce greenhouse gas emissions from agricultural production? Agric. Hum. Values 2015, 32, 255-263. [CrossRef]

70. Lorenz, K.; Lal, R. Environmental impact of organic agriculture. Adv. Agron. 2016, 139, 99-152. [CrossRef]

71. Barbieri, P.; Pellerin, S.; Nesme, T. Comparing crop rotations between organic and conventional farming. Sci. Rep. 2017, 7, 1-10. [CrossRef]

72. European Commission. Commission regulation (EU) No 1258/2011 of 2 december 2011 amending regulation (EC). In: No 1881/2006 as Regards Maximum Levels for Nitrates in Foodstuffs. Off. J. Eur. Union 2011, L320/315, 15-17.

73. Løes, A.-K.; Bünemann, E.K.; Cooper, J.; Hörtenhuber, S.; Magid, J.; Oberson, A.; Möller, K. Nutrient supply to organic agriculture as governed by EU regulations and standards in six European countries. Org. Agric. 2017, 7, 395-418. [CrossRef]

74. Hartmann, M.; Frey, B.; Mayer, J.; Mäder, P.; Widmer, F. Distinct soil microbial diversity under long-term organic and conventional farming. ISME J. 2015, 9, 1177-1194. [CrossRef] [PubMed]

75. Lori, M.; Symnaczik, S.; Mäder, P.; De Deyn, G.; Gattinger, A.; Dentener, F. Organic farming enhances soil microbial abundance and activity-A meta-analysis and meta-regression. PLoS ONE 2017, 12, 1-25. [CrossRef]

76. Bhogal, A.; Williams, J.R.; Nicholson, F.A.; Chadwick, D.R.; Chambers, K.H.; Chambers, B.J. Mineralization of organic nitrogen from farm manure applications. Soil Use Manag. 2016, 32, 32-43. [CrossRef]

77. IPCC: Guidelines for National Greenhouse Gas Inventories. Agriculture, Forestry and Other Land Use, International Panel of Climate Change. 2006. Available online: https:/ / www.ipcc-nggip.iges.or.jp/public/2006gl/index (accessed on 27 September 2021). 
78. Krauss, M.; Ruser, R.; Müller, T.; Hansen, S.; Mäder, P.; Gattinger, A. Impact of reduced tillage on greenhouse gas emissions and soil carbon stocks in an organic grass-clover ley-winter wheat cropping sequence. Agric. Ecosyst. Environ. 2017, 239, $324-333$. [CrossRef]

79. Charles, A.; Rochette, P.; Whalen, J.K.; Angers, D.A.; Chantigny, M.H.; Bertrand, N. Global nitrous oxide emission factors from agricultural soils after addition of organic amendments: A meta-analysis. Agric. Ecosyst. Environ. 2017, 236, 88-98. [CrossRef]

80. Baral, K.R.; Labouriau, R.; Olesen, J.E.; Petersen, S.O. Nitrous oxide emissions and nitrogen use efficiency of manure and digestates applied to spring barley. Agric. Ecosyst. Environ. 2017, 239, 188-198. [CrossRef]

81. Hefner, M.; Canali, S.; Willekens, K.; Lootens, P.; Deltour, P.; Beeckmand, A.; Arlotti, D.; Tamm, K.; Benderg, I.; Labouriauh, R.; et al. Termination method and time of agro-ecological service crops influence soil mineral nitrogen, cabbage yield and root growth across five locations in Northern and Western Europe. Eur. J. Agron. 2020, 120, 126144. [CrossRef]

82. Valkama, E.; Lemola, R.; Känkänen, H.; Turtola, E. Meta-analysis of the effects of undersown catch crops on nitrogen leaching loss and grain yields in the Nordic countries. Agric. Ecosyst. Environ. 2015, 203, 93-101. [CrossRef]

83. Tosti, G.; Benincasa, P.; Farneselli, M.; Tei, F.; Guiducci, M. Barley-hairy vetch mixture as cover crop for green manuring and the mitigation of $\mathrm{N}$ leaching risk. Eur. J. Agron. 2014, 54, 34-39. [CrossRef]

84. Tosti, G.; Farneselli, M.; Benincasa, P.; Guiducci, M. Nitrogen fertilization strategies for organic wheat production: Crop yield and nitrate leaching. Agron. J. 2016, 108, 770-781. [CrossRef]

85. Frasier, I.; Noellemeyer, E.; Amiotti, N.; Quiroga, A. Vetch-rye biculture is a sustainable alternative for enhanced nitrogen availability and low leaching losses in a no-till cover crop system. Field Crop. Res. 2017, 214, 104-112. [CrossRef]

86. Navarro-Miro, D.; Blanco-Moreno, J.M.; Ciaccia, C.; Chamorro, L.; Testani, E.; Kristensen, H.L.; Hefner, M.; Tamm, K.; Bender, I.; Jakop, M.; et al. Agroecological service crops managed with roller crimper reduce weed density and weed species richness in organic vegetable systems across Europe. Agron. Sust. Dev. 2019, 39, 1-13. [CrossRef]

87. Navarro-Miro, D.; Iocola, I.; Persiani, A.; Blanco-Moreno, J.M.; Kristensen, H.L.; Hefner, M.; Tamm, K.; Bender, I.; Vedie, H.; Willekens, K.; et al. Energy flows in European organic vegetable systems: Effects of the introduction and management of agroecological service crops. Energy 2019, 188, 116096. [CrossRef]

88. Canali, S.; Campanelli, G.; Ciaccia, C.; Leteo, F.; Testani, E.; Montemurro, F. Conservation tillage strategy based on the roller crimper technology for weed control in Mediterranean vegetable organic cropping systems. Eur. J. Agron. 2013, 50, 11-18. [CrossRef]

89. Singh, G.; Williard, K.; Schoonover, J.; Nelson, K.A.; Kaur, G. Cover crops and landscape position effects on nitrogen dynamics in plant-soil-water pools. Water 2019, 11, 513. [CrossRef]

90. Meisinger, J.J.; Ricigliano, K.A. Nitrate leaching from winter cereal cover crops using undisturbed soil-column lysimeters. J. Environ. Qual. 2017, 46, 576-584. [CrossRef] [PubMed]

91. Singh, G.; Thilakarathne, A.D.; Williard, K.W.; Schoonover, J.E.; Cook, R.L.; Gage, K.; McElroy, R. Tillage and legume nonlegume cover cropping effects on corn-soybean production. Agron. J. 2020, 112, 2636-2648. [CrossRef]

92. Contosta, A.R.; Arndt, K.A.; Campbell, E.E.; Grandy, A.S.; Perry, A.; Varne, R.K. Management intensive grazing on New England dairy farms enhances soil nitrogen stocks and elevates soil nitrous oxide emissions without increasing soil carbon. Agric. Ecosyst. Environ. 2021, 317, 107471. [CrossRef]

93. Wang, T.; Teague, W.R.; Park, S.C.; Bevers, S. Evaluating long-term economic and ecological consequences of continuous and multi-paddock grazing-a modeling approach. Agric. Syst. 2018, 165, 197-207. [CrossRef]

94. USDA-NASS. Census of Agriculture. In: Agriculture, USDA 2017. Available online: https:/ /www.nass.usda.gov/Publications / AgCensus /2017/index.php (accessed on 27 September 2021).

95. Gosnell, H.; Charnley, S.; Stanley, P. Climate change mitigation as a co-benefit of regenerative ranching: Insights from Australia and the United States. Interface Focus 2020, 10, 20200027. [CrossRef]

96. Teague, W.R.; Apfelbaum, S.; Lal, R.; Kreuter, U.P.; Rowntree, J.; Davies, C.A.; Conser, R.; Rasmussen, M.; Hatfield, J.; Wang, T.; et al. The role of ruminants in reducing agriculture's carbon footprint in North America. J. Soil Water Conserv. 2016, 71, 156-164. [CrossRef]

97. Teague, R.; Barnes, M. Grazing management that regenerates ecosystem function and grazingland livelihoods. Afr. J. Range Forage Sci. 2017, 34, 77-86. [CrossRef]

98. Teutscherova, N.; Vazquez, E.; Sotelo, M.; Villegas, D.; Velasquez, N.; Baquero, D.; Pulleman, M.; Arango, J. Intensive shortduration rotational grazing is associated with improved soil quality within one year after establishment in Colombia. Appl. Soil Ecol. 2021, 159, 103835. [CrossRef]

99. Gu, J.; Yuan, M.; Liu, J.; Hao, Y.; Zhou, Y.; Qu, D.; Yang, X. Trade-off between soil organic carbon sequestration and nitrous oxide emissions from winter wheat-summer maize rotations: Implications of a 25-year fertilization experiment in Northwestern China. Sci. Total Environ. 2017, 595, 371-379. [CrossRef] [PubMed]

100. Lugato, E.; Leip, A.; Jones, A. Mitigation potential of soil carbon management overestimated by neglecting $\mathrm{N}_{2} \mathrm{O}$ emissions. Nat. Clim. Chang. 2018, 8, 219-223. [CrossRef]

101. Xia, L.; Lam, S.K.; Wolf, B.; Kiese, R.; Chen, D.; Butterbach-Bahl, K. Trade-offs between soil carbon sequestration and reactive nitrogen losses under straw return in global agroecosystems. Glob. Chang. Biol. 2018, 24, 5919-5932. [CrossRef]

102. Deng, Q.; Hui, D.; Wang, J.; Yu, C.-L.; Li, C.; Reddy, K.C.; Dennis, S. Assessing the impacts of tillage and fertilization management on nitrous oxide emissions in a cornfield using the DNDC model. J. Geophys. Res. Biogeosci. 2016, 121, 337-349. [CrossRef] 
103. Sadras, V.O.; Hayman, P.T.; Rodriguez, D.; Monjardino, M.; Bielich, M.; Unkovich, M.; Mudge, B.; Wang, E. Interactions between water and nitrogen in Australian cropping systems: Physiological, agronomic, economic, breeding and model $\neg$ ling perspectives. Crop Pasture Sci. 2016, 67, 1019. [CrossRef]

104. Chen, Z.; Liu, C.; Wang, Y.; He, T.; Gao, R.; Xu, H.; Guo, G.; Li, Y.; Zhou, L.; Lu, R.; et al. Expression analysis of nitrogen metabolism-related genes reveals differences in adaptation to low-nitrogen stress between two different barley cultivars at seedling stage. Hindawi Int. J. Genomics 2018, 2018, 1-10. [CrossRef] [PubMed]

105. Krapp, A.; David, L.C.; Chardin, C.; Girin, T.; Marmagne, A.; Leprince, A.S. Nitrate transport and signallingin Arabidopsis. J. Exp. Bot. 2014, 65, 789-798. [CrossRef] [PubMed]

106. Maurel, C.; Verdoucq, L.; Rodrigues, O. Aquaporins and plant transpiration. Plant Cell Environ. 2016, 39, 2580-2587. [CrossRef]

107. Ishikawa-Sakurai, J.; Hayashi, H.; Murai-Hatano, M. Nitrogen availability affects hydraulic conductivity of rice roots, possibly through changes in aquaporin gene expression. Plant Soil 2014, 379, 289-300. [CrossRef]

108. Remans, T.; Nacry, P.; Pervent, M.; Girin, T.; Tillard, P.; Lepetit, M.; Gojon, A. A central role for the nitrate transporter NRT2.1 in the integrated morphological and physiological responses of the root system to nitrogen limitation in Arabidopsis. Plant Physiol. 2006, 140, 909-921. [CrossRef]

109. Little, D.Y.; Rao, H.; Oliva, S.; Daniel-Vedele, F.; Krapp, A.; Malamy, J.E. The putative high-affinity nitrate transporter NRT2.1 represses lateral root initiation in response to nutritional cues. Proc. Natl. Acad. Sci. USA 2005, 102, 13693-13698. [CrossRef]

110. Hu, H.; Wang, Y.; Tsay, Y. AtCIPK8, a CBL-interacting protein kinase, regulates the low-affinity phase of the primary nitrate response. Plant J. 2009, 57, 264-278. [CrossRef]

111. Vidal, E.A.; Karem, V.; Tamayo, P.; Rodrigo, P.; Gutierrez, A. Gene networks for nitrogen sensing, signaling, and response in Arabidopsis thaliana.Wiley Interdiscip. Rev. Syst. Biol. Med. 2010, 2, 683-693. [CrossRef]

112. Peng, M.; Hannam, C.; Gu, H.; Bi, Y.-M.; Rothstein, S.J. A mutation in NLA, which encodes a RING-type ubiquitin ligase, disrupts the adaptability of Arabidopsis to nitrogen limitation. Plant J. 2007, 50, 320-337. [CrossRef]

113. Peng, M.; Hudson, D.; Schofield, A.; Tsao, R.; Yang, R.; Gu, H.; Bi, Y.-M.; Rothstein, S.J. Adaptation of Arabidopsis to nitrogen limitation involves induction of anthocyanin synthesis which is controlled by the NLA gene. J. Exp. Bot. 2008, 59, 2933-2944. [CrossRef] [PubMed]

114. Castaings, L.; Camargo, A.; Pocholle, D.; Gaudon, V.; Texier, Y.; Boutet-Mercey, S.; Taconnat, L.; Renou, J.P.; Daniel-Vedele, F.; Fernandez, E.; et al. The nodule inception-like protein 7 modulates nitrate sensing and metabolism in Arabidopsis. Plant J. 2008, 57, 426-435. [CrossRef]

115. Pant, B.D.; Buhtz, A.; Kehr, J.; Scheible, W.R. MicroRNA399 is a long-distance signal for the regulation of plant phosphate homeostasis. Plant J. 2008, 53, 731-738. [CrossRef]

116. Voinnet, O. Origin, biogenesis, and activity of plant microRNAs. Cell 2009, 136, 669-687. [CrossRef]

117. Gutierrez, R.A.; Lejay, L.V.; Dean, A. Qualitative network models and genome-wide expression data define carbon/nitrogenresponsive molecular machines in Arabidopsis. Genome Biol. 2007, 8, 37. [CrossRef]

118. Gifford, M.L.; Dean, A.; Gutierrez, R.A.; Coruzzi, G.M.; Birnbaum, K.D. Cell-specific nitrogen responses mediate developmental plasticity. Proc. Natl. Acad. Sci. USA 2008, 105, 803-808. [CrossRef]

119. Pant, B.D.; Musialak-Lange, M.; Nuc, P.; May, P.; Buhtz, A.; Kehr, J.; Walther, D.; Scheible, W.R. Identification of nutrientresponsive Arabidopsis and rapeseed MicroRNAs by comprehensive Real-Time Polymerase Chain Reaction profiling and small RNA sequencing. Plant Physiol. 2009, 150, 1541-1555. [CrossRef] [PubMed]

120. Kollaricsné Horváth, M.; Hoffmann, B.; Cernák, I.; Baráth, S.; Polgár, Z.; Taller, J. Nitrogen utilization of potato genotypes and expression analysis of genes controlling nitrogen assimilation. Biol. Fut. 2019, 70, 25-37. [CrossRef] [PubMed]

121. Yang, G.D.; Zhou, Y.F.; Huang, R.; Lin, F.; Hu, Z.Y.; Hao, Z.Y.; Liang, C.B.; Wang, Q.; Meng, X.X.; Dong, L.D. Identification of differentially expressed genes of Sorghum [Sorghum Bicolor (L.) Moench] seedlings under nitrogen stress by RNA-Seq. Appl. Ecol. Environ. Res. 2019, 17, 11525-11536. [CrossRef]

122. Karwowska, M.; Kononiuk, A. Nitrates/nitrites in food-risk for nitrosative stress and benefits. Antioxidants 2020, 9, 241. [CrossRef]

123. Hakeem, K.R.; Sabir, M.; Ozturk, M.; Akhtar, M.S.; Ibrahim, F.H. Nitrate and nitrogen oxides: Sources, health effects and their remediation. Rev. Environ. Contam. Toxicol. 2017, 242, 183-217. [CrossRef] [PubMed]

124. Beule, L.; Corre, M.D.; Schmidt, M.; Gobel, L.; Veldkamp, E.; Karlovsky, P. Conversion of monoculture cropland and open grassland to agroforestry alters the abundance of soil bacteria, fungi and soil-N-cycling genes. PLoS ONE 2019, 14 , e02187. [CrossRef]

125. Tang, L.; Luo, W.J.; He, Z.L.; Gurajala, H.K.; Hamid, Y.; Khan, K.Y.; Yang, X.E. Variations in cadmium and nitrate co-accumulation among water spinach genotypes and implications for screening safe genotypes for human consumption. J. Zhejiang Univ. -Sci. B 2018, 19, 147-158. [CrossRef]

126. Meng, F.; Qiao, Y.; Wu, W.; Smith, P.; Scott, S. Environmental impacts and production performances of organic agriculture in China: A monetary valuation. J. Environ. Manag. 2017, 188, 49-57. [CrossRef] [PubMed]

127. Tegeder, M.; Masclaux-Daubresse, C. Source and sink mechanisms of nitrogen transport and use. New Phytol. 2018, 17, 35-53. [CrossRef]

128. Salehzadeh, H.; Maleki, A.; Rezaee, R.; Shahmoradi, B.; Ponnet, K. The nitrate content of fresh and cooked vegetables and their health-related risks. PLoS ONE 2020, 15, e0227551. [CrossRef] [PubMed] 
129. Ahmed, M.; Rauf, M.; Mukhtar, Z.; Saeed, N.A. Excessive use of nitrogenous fertilizers: An unawareness causing serious threats to environment and human health. Environ. Sci. Pollut. Res. Int. 2017, 24, 26983-26987. [CrossRef] [PubMed]

130. Li, H.; Zhang, Y. Abnormal ratio of nitrate to ammonium nitrogen fertilizers in China. J. Agric. Food Chem. 2020, 68, 701-702. [CrossRef]

131. Anglade, J.; Medina, M.R.; Billen, G.; Garnier, J. Organic market gardening around the Paris agglomeration: Agro-environmental performance and capacity to meet urban requirements. Environ. Sci. Pollut. Res. Int. 2018, 25, 23373-23382. [CrossRef] [PubMed]

132. Colla, G.; Kim, H.J.; Kyriacou, M.C.; Rouphael, Y. Nitrates in fruits and vegetables. Sci. Hortic. 2018, 237, 221-238. [CrossRef]

133. Iammarino, M.; Di Taranto, A.; Cristino, M. Monitoring of nitrites and nitrate levels in leafy vegetables (spinach and lettuce): A contribution to risk assessment. J. Sci. Food Agric. 2014, 94, 773-778. [CrossRef] [PubMed]

134. Kmecl, V.; Znidarcic, D.; Franic, M.; Ban, S.G. Nitrate and nitrite contamination of vegetables in the Slovenian market. Food Addit. Contam. Part B 2019, 12, 216-223. [CrossRef] [PubMed]

135. Kyriacou, M.C.; Soteriou, G.A.; Colla, G.; Rouphael, Y. The occurrence of nitrate and nitrite in Mediterranean fresh salad vegetables and its modulation by preharvest practices and postharvest conditions. Food Chem. 2019, 285, 468-477. [CrossRef] [PubMed]

136. Liu, A.H.; Bondonno, C.P.; Russell, J.; Flood, V.M.; Lewis, J.R.; Croft, K.D.; Woodman, R.J.; Lim, W.H.; Kifley, A.; Wong, G.; et al. Relationship of dietary nitrate intake from vegetables with cardiovascular disease mortality: A prospective study in a cohort of older Australians. Eur. J. Nutr. 2019, 8, 2741-2753. [CrossRef]

137. Yang, T.; Zhang, X.M.; Tarnawski, L.; Peleli, M.; Zhuge, Z.; Terrando, N.; Harris, R.A.; Olofsson, P.S.; Larsson, E.; Persson, A.E.G.; et al. Dietary nitrate attenuates renal ischemia-reperfusion injuries by modulation of immune responses and reduction of oxidative stress. Redox Biol. 2017, 13, 320-330. [CrossRef]

138. Jones, A.M.; Thompson, C.; Wylie, L.J.; Vanhatalo, A. Dietary nitrate and physical performance. Annu. Rev. Nutr. 2018, 38, 303-328. [CrossRef]

139. Zand, J.; Lanza, F.; Garg, H.K.; Bryan, N.S. All-natural nitrite and nitrate containing dietary supplement promotes nitric oxide production and reduces triglycerides in humans. Nutr. Res. 2011, 31, 262-269. [CrossRef]

140. IARC. Ingested nitrate and nitrite, and cyanobacterial peptide toxins. IARC Monogr. Eval. Carcinog. Risks Hum. 2010, 94, 1-464.

141. Kobayashi, J.; Ohtake, K.; Uchida, H. NO-rich diet for lifestyle-related diseases. Nutrients 2015, 7, 4911-4937. [CrossRef]

142. EFSA. Statement on possible public health risks for infants and young children from the presence of nitrates in leafy vegetables. EFSA J. 2010, 8, 1935. [CrossRef]

143. León, V.M.; Luzardo, O.P. Evaluation of nitrate contents in regulated and non-regulated leafy vegetables of high consumption in the Canary Islands, Spain: Risk assessment. Food Chem. Toxicol. 2020, 146, 111812. [CrossRef]

144. Cavaiuolo, M.; Ferrante, A. Nitrates and glucosinolates as strong determinants of the nutritional quality in rocket leafy salads. Nutrients 2014, 6, 1519-1538. [CrossRef]

145. Liu, C.W.; Sung, Y.; Chen, B.C.; Lai, H.Y. Effects of nitrogen fertilizers on the growth and nitrate content of lettuce (Lactuca sativa L.). Int. J. Environ. Res. Public Health 2014, 11, 4427-4440. [CrossRef] [PubMed]

146. Petropoulos, S.A.; Olympios, C.M.; Passam, H.C. The effect of nitrogen fertilization on plant growth and the nitrate content of leaves and roots of parsley in the Mediterranean region. Sci. Hortic. 2008, 118, 255-259. [CrossRef]

147. Konstantopoulou, E.; Kapotis, E.; Salachas, G.; Petropoulos, S.A.; Karapanos, I.C.; Passam, H.C. Nutritional quality of greenhouse lettuce at harvest and after storage in relation to $\mathrm{N}$ application and cultivation season. Sci. Hortic. 2010, 125, 93.e1-93.e5. [CrossRef]

148. Koh, E.; Charoenprasert, S.; Mitchell, A.E. Effect of organic and conventional cropping systems on ascorbic acid, vitamin C, flavonoids, nitrate, and oxalate in 27 varieties of spinach (Spinacia oleracea L.). J. Agric. Food Chem. 2012, 60, 3144-3150. [CrossRef]

149. Nunez de Gonzalez, M.T.; Osburn, W.N.; Hardin, M.D.; Longnecker, M.; Garg, H.K.; Bryan, N.S.; Keeton, J.T. A survey of nitrate and nitrite concentrations in conventional and organic-labeled raw vegetables at retail. J. Food Sci. 2015, 80, C942-C949. [CrossRef] [PubMed]

150. Farias, G.D.; Dubeux, J.C.B., Jr.; Savian, J.V.; Duarte, L.P.; Martins, A.P.; Alves, L.A.; de Faccio Carvalho, P.C.; Bremm, C. Integrated crop-livestock system with system fertilization approach improves food production and resource-use efficiency in agricultural lands. Agron. Sustain. Dev. 2020, 40, 39. [CrossRef]

151. Di, H.; Cameron, K. Nitrate leaching in temperate agroecosystems: Sources, factors and mitigating strategies. Nutr. Cycl. Agroecosystems 2002, 64, 237-256. [CrossRef]

152. Dungait, J.A.; Cardenas, L.M.; Blackwell, M.S.; Wu, L.; Withers, P.J.; Chadwick, D.R.; Bol, R.; Murray, P.J.; Macdonald, A.J.; Whitmore, A.P.; et al. Advances in the understanding of nutrient dynamics and management in UK agriculture. Sci. Total Environ. 2012, 434, 39-50. [CrossRef]

153. Dahal, S.; Franklin, D.; Subedi, A.; Cabrera, M.; Hancock, D.; Mahmud, K.; Ney, L.; Park, C.; Mishra, D.J.S. Strategic grazing in beef-pastures for improved soil health and reduced runoff-nitrate-A step towards. Sustainability 2020, 12, 558. [CrossRef]

154. Meng, Y.; Wang, J.J.; Wei, Z.; Dodla, S.K.; Fultz, L.M.; Gaston, L.A.; Xiao, R.; Park, J.-h.; Scaglia, G. Nitrification inhibitors reduce nitrogen losses and improve soil health in a subtropical pastureland. Geoderma 2021, 388, 114947. [CrossRef]

155. Chen, Y.; Fan, P.; Mo, Z.; Kong, L.; Tian, H.; Duan, M.; Li, L.; Wu, L.; Wang, Z.; Tang, X. Deep placement of nitrogen fertilizer affects grain yield, nitrogen recovery efficiency, and root characteristics in direct-seeded rice in south China. J. Plant. Growth Regul. 2020, 40, 379-387. [CrossRef] 
156. Chatterjee, D.; Mohanty, S.; Guru, P.K.; Swain, C.K.; Tripathi, R.; Shahid, M.; Kumar, U.; Kumar, A.; Bhattacharyya, P.; Gautam, P.; et al. Comparative assessment of urea briquette applicators on greenhouse gas emission, nitrogen loss and soil enzymatic activities in tropical lowland rice. Agric. Ecosyst. Environ. 2018, 252, 178-190. [CrossRef]

157. Mencaroni, M.; Dal Ferro, N.; Furlanetto, J.; Longo, M.; Lazzaro, B.; Sartori, L.; Grant, B.; Smith, W.; Morari, F. Identifying N fertilizer management strategies to reduce ammonia volatilization: Towards a site-specific approach. J. Environ. Manag. 2021, 277, 111445. [CrossRef] [PubMed]

158. Mobin, S.; Alam, F. Biofuel production from algae utilizing wastewater. In Proceedings of the 19th Australasian Fluid Mechanics Conference, Melbourne, Australia, 8-11 December 2014.

159. Dang, N.M.; Lee, K. Recent trends of using alternative nutrient sources for microalgae cultivation as a feedstock of biodiesel production. Appl. Chem. Eng. 2018, 29, 1-9.

160. Webb, J.R.; Hayes, N.M.; Simpson, G.L.; Leavitt, P.R.; Baulch, H.M.; Finlay, K. Widespread nitrous oxide undersaturation in farm waterbodies creates an unexpected greenhouse gas sink. Proc. Natl. Acad. Sci. USA 2019, 116, 9814-9819. [CrossRef] [PubMed]

161. Ibort, P.; Imai, H.; Uemura, M.; Aroca, R. Proteomic analysis reveals that tomato interaction with plant growth promoting bacteria is highly determined by ethylene perception. J. Plant Physiol. 2018, 220, 43-59. [CrossRef] [PubMed]

162. Brusamarello-Santos, L.C.; Gilard, F.; Brulé, L.; Quilleré, I.; Gourion, B.; Ratet, P.; Maltempi de Souza, E.; Lea, P.J.; Hirel, B. Metabolic profiling of two maize (Zea mays L.) inbred lines inoculated with the nitrogen fixing plant-interacting bacteria Herbaspirillum seropedicae and Azospirillum brasilense. PLoS ONE 2017, 12, e0174576. [CrossRef] [PubMed]

163. Candido, V.; Boari, F.; Cantore, V.; Castronuovo, D.; Di Venere, D.; Perniola, M.; Sergio, L.; Viggiani, R.; Schiattone, M.I. Interactive effect of nitrogen and Azoxystrobin on yield, quality, nitrogen and water use efficiency of wild rocket in southern Italy. Agronomy 2020, 10, 849. [CrossRef] 